\title{
Horse remains from the Gnezdovo archaeological complex, Smolensk Region, Russia
}

\author{
Irina V. Kirillova* \& Natalia N. Spasskaya
}

\begin{abstract}
The paper summarizes results of the archaeozoological and taphonomic studies of the osteological materials from floodplain settlement (complexes "Nastil 2", "Fire 1") and burial mounds of the medieval Gnezdovo. Mostly cranial remnants of the complex "Nastil 2" are characteristic of so-called "storages" sacrifice, which is recorded for this site for the first time. Animal bones of the "Fire 1" layer were heavily affected by the fire that changed bone tissues in various degrees depending on the temperature. Horse remains of the burial mounds Ts-255 also bear traces of a fire affect, which could be indirect (for example, through a thin soil layer). It changes previous idea of the way the inhumation by indicating cremation. Horse remains of the Gnezdovo show differences in the size class and proportion of skeletal elements. Gracile first phalanges of the horse of the Ts-191 burial indicate their belonging to a southern race. This feature is absent in other remains thus suggesting heterogeneity of the horse breed composition in the Gnezdovo. This is consistent both with the heterogeneity of ethnic composition and with the presence of imported artifacts in the burials. Specificity of the Gnezdovo burials with horses (a separate horse burials; a burial of a rider with his horse; a horse belonging to one owner) demonstrates a special relationship of the residents with riding horses.
\end{abstract}

KEY WORDS: burial, horse, Gnezdovo archaeological complex, Middle Ages.

Irina V. Kirillova [ikirillova@yandex.ru], "Ice Age” Museum, All-Russian Exhibition Centre, Bld. 71, Moscow, 129223, Russia; Natalia N. Spasskaya [equusnns@mail.ru], Zoological Museum of the Lomonosov Moscow State University, Bol'shaya Nikitskaya st., 6, Moscow, 125009, Russia

\section{Остатки лошадей из археологического комплекса Гнёздово, Смоленская область, Россия}

\section{И.В. Кириллова, Н.Н. Спасская}

РЕЗЮМЕ. Представлены результаты археозоологического и тафономического изучения остеологических материалов из пойменной части поселения (комплексы «Настил 2», «Пожар») и курганов археологического комплекса Гнёздово. Преимущественно черепные остатки из комплекса «Настил 2» характерны для так называемых «закладных» жертв, которые отмечены для памятника впервые. Кости животных из слоя «Пожар» претерпели значительные изменения из-за теплового воздействия, изменившего костную ткань в различной степени, в зависимости от температуры. Кости лошади из кургана Ц-225 также несут следы термического воздействия, которое могло быть и опосредованным (например, через тонкий слой грунта). Это корректирует прежнее мнение о способе погребении (ингумация) и скорее указывает на кремацию. Выявлены различия в размерах и пропорциях костей и индивидуальные особенности. Грацильность первых фаланг, отмеченная только для скелета лошади из кургана Ц-191, указывает на её принадлежность к южной породной группе и неоднородность породного состава в целом. Это согласуется с этнической неоднородностью населения, отмеченной антропологами, и привозными предметами в погребениях. Специфика Гнёздовских погребений с верховыми лошадьми (отдельное погребение лошади; захоронение всадника с конём; конь, принадлежавший одному хозяину) демонстрирует особое отношение жителей к ним.

КЛЮЧЕВЫЕ СЛОВА: захоронения, лошади, Гнёздовский археологический комплекс, Средневековье. 


\section{Introduction}

The Gnezdovo archaeological site has been studying during more than 130 years, providing extensive collection and data on the economic structure, economic relationships, natural conditions and time of the formation of particular objects and layers of the complex. Some principal questions concerning history of the Vladimir-Suzdal Rus' have been resolved. The most important materials were obtained by excavation in the Gnezdovo necropolis, which includes about 4.5 thousand burial mounds dated from the beginning of the 10th century to the beginning of the 11 th century (Avdusin, 1991). Among the burials, complexes with burnt corpses prevail containing bones of various animals, in particular horses. The mounds of the Central group include 26 complexes of this sort (40.9\% of mounds), ten of them containing horse bones (Zharnov, 1992). The first explorers of Gnezdovo reported about several complete horse skeletons and skulls (Sizov, 1902; Spitsyn, 1905). Unfortunately, they have been lost subsequently without examination. Andreeva (1980) provided the only archaeozoological publication devoted to burial mounds. Osteological materials from the site of ancient settlements of Gnezdovo are only partially investigated by now and poorly considered in publications. At the same time, few works considering the bone specimens provide some information valuable for reconstruction of the life of medieval Gnezdovo population (Ermolova, 1967; Andreeva, 1963, 1980; Kirillova, 2007). New materials obtained during recent excavations and the study of previously collected bone specimens allowed a better understanding of this unique archaeological complex. The present study provides results of a new investigation of those materials.

\section{Materials and methods}

We studied materials of two complexes:

A. Floodplain part of the settlement (excavated by V.V. Murasheva, The State Historical Museum, 20052006): (1) object "Nastil 2", dated latter half of the $10^{\text {th }}$ century, and (2) "Pozhar 1" layer, the terminal layer of the settlement of Gnezdovo, dated the boundary of the $10^{\text {th }}-11^{\text {th }}$ centuries.

B. Horse skeletons from three burial mounds of the Central group of Gnezdovo: Ts-142, Ts-191 and Ts255 (excavated by a Smolensk archaeological expedition of Moscow State University (MSU) in 1975-1978). The first two skeletons (specimen nos. S-106950 and S106951, respectively) are preserved owing to E.G. Andreeva in the collection of the Zoological Museum of MSU (ZMMU). The third comes from burial Ts-255, it is stored at the Archaeological Department of the Historical Faculty of MSU, however, the skull, except for small fragments, is absent. This skeleton was transferred to the Zoological Museum of MSU in 2009 (specimen no. S-186120).
We also examined copies of archive materials stored at the Archaeological Department of the Historical Faculty of MSU.

Postcranial bones and tooth row were measured following the method proposed by Gromova (1959, 1963) and Eisenmann et al. (1988), using callipers (with a metering error of $0.1 \mathrm{~mm}$ ). The individual age and sex of animals was determined based on the extent of tooth eruption and wear (Kuleshov \& Krasnikov, 1928; Korneven \& Lesbr, 1932; Dyurst, 1936), taking into account the condition of cranial and postcranial bones (obliteration of sutures, state of compacta, etc.).

To estimate the horse body height, we used the length of limb bones corrected by coefficients of Kiesewalter (1888) and Gromova (1949, 1959, 1963). For the metacarpal and the metatarsal, the correction coefficients are 6.41 and 5.33, respectively. Classification of size groups of horses is adopted after Vitt (1952). It is based both on reconstructed withers height (on Kizewalter) and on the size of particular bones. These two systems of evaluation of the horse size provide slightly different results. Although Vitt had criticized Kiesewalter's approach, our checking of Kiesewalter's coefficients for metapodial bones showed that this method provides most precise estimation of the withers height measured in the same live animals (Spasskaya, 1999).

\section{Description}

\section{A. Horse bones from the floodplain part of Gnezdovo}

Bones from the "Nastil 2" complex are mostly poorly preserved; many of them being affected by fire. Only teeth are completely preserved. Table 1 shows composition of the animal remains. As it follows from the Table 1, the specimens are mostly skull fragments and teeth of the horse, cattle and pig. In each case, the bones preserved in one site belonged to the same adult individual. Bones from the "Pozhar 1" layer are of intermediate preservation, some are poorly preserved, considerably fragmented, brownish-reddish, frequently with non-uniform dark grey and black spots. A distinctive feature of the assemblage is a great proportion of bones that underwent the influence of fire, 246 specimens of 816 . However, these data are based on the condition of bone surface and do not correspond to the true number of burned specimens, since the surface often lacks a trace of the effect of high temperature, but as the bones are broken their spongy tissue is often smoked or burnt, or similar traces are seen on the planes of bone cracks. In particular, pig teeth are frequently represented by enamel crowns, which are more resistant, while dentine of the crown and roots is strongly charred and easily crumbled, or even absent. The same is true for the teeth of Equus and Bos, with the only difference caused by greater height of their crowns, so that they seem complete, although their dentin filling is also easily crumbled. A prominent manifestation of taphonomic fea- 
Table 1. Composition of mammal remains from the "Nastil 2" complex.

\begin{tabular}{|l|c|l|c|}
\hline \multicolumn{1}{|c|}{ Taxon } & $\begin{array}{c}\text { Number of } \\
\text { specimens }\end{array}$ & \multicolumn{1}{|c|}{ Skeletal elements } & Size class \\
\hline $\begin{array}{l}\text { Equus caballus, } \\
\text { horse }\end{array}$ & 16 & $\begin{array}{l}\text { skull (4 fragments), upper cheek teeth (11, including 10 } \\
\text { complete); scapula (1) }\end{array}$ & $\mathrm{m}$ \\
\hline Bos taurus, cattle & 38 & $\begin{array}{l}\text { skull (8 fragments), upper and lower cheek teeth (25, including } \\
\text { 1 complete), metatarsal (2), ankle bone (1), calcaneus (1), } \\
\text { phalanx 2 (1) }\end{array}$ & $\mathrm{sm}$ \\
\hline Sus domesticus, pig & 7 & $\begin{array}{l}\text { skull (1, strongly damaged), upper teeth cheek (6, including 4 } \\
\text { complete), female }\end{array}$ & $\mathrm{sm}$ \\
\hline Larger ungulates & 121 & Small fragments of skulls and teeth & \\
\hline Total & 182 & \multicolumn{2}{l}{} \\
\hline
\end{tabular}
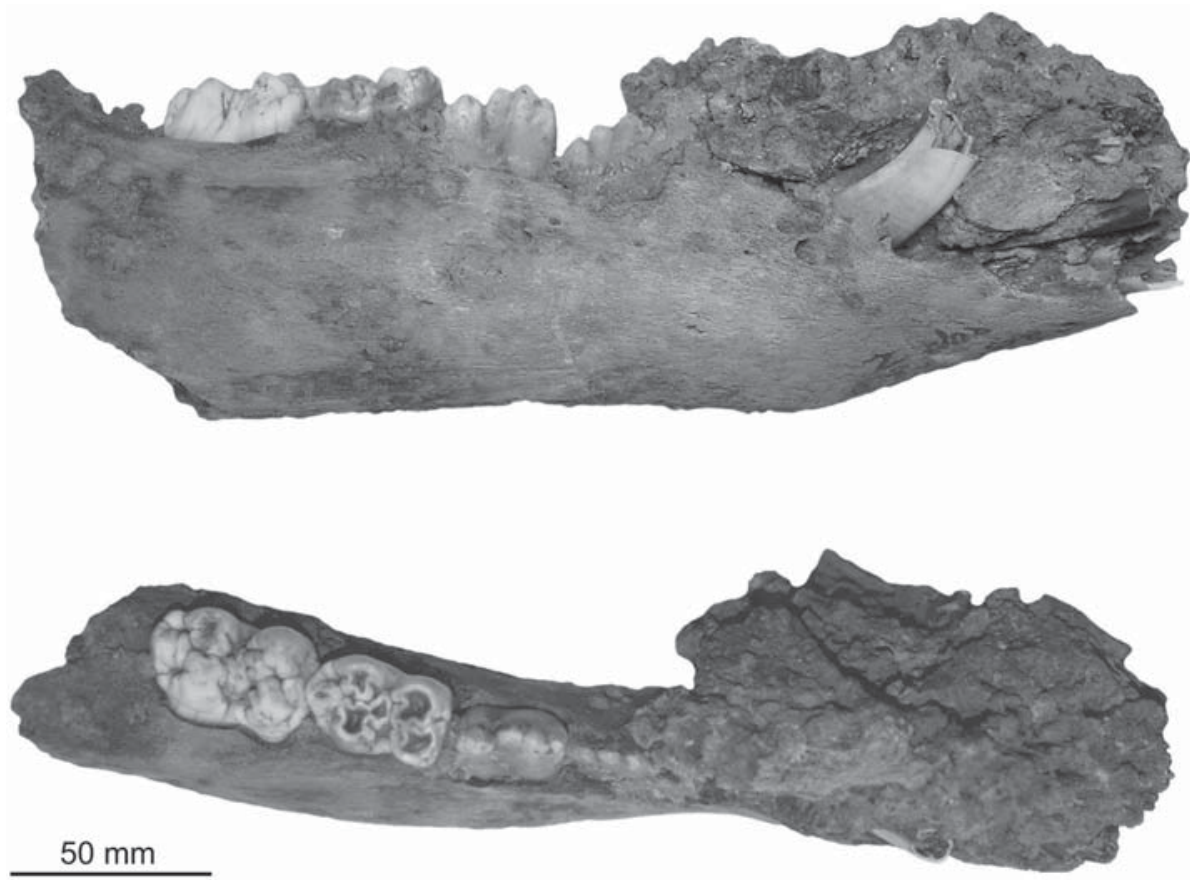

Fig. 1. Slag fused with the mandibular symphysis of domestic pig (SHM, without number).

tures of the "Pozhar 1" layer is provided by the right mandible of a young pig with symphysis containing a conglomerate of small coals, bone fragments and sand particles (Fig. 1). A similar effect is observed as one throws an object on live coals of a stove in order to bake rather than burn it. Actually, this conglomerate is a slag fused with the bone.

Table 2 shows the composition of animal remains in the "Pozhar 1" layer.

Some characteristics of bones from the "Pozhar 1" layer are as following:

Cattle. The proximal part of metacarpal 1 displays malformation in bone tissue (periosteosis). The distal metatarsal fragments ( 7 specimens) are represented by a series a similarly treated bones. However, because of poor preservation, the specimens lack a trace of treatment (cuts etc.). This was probably fragmentation during preparation. These bones belong mostly to adults.

Pig. The mandibles belong to three females and two males. The individual age of two subadults represented by three jaws is identified as 18-20 months old based on the condition of dentition $\left(\mathrm{M}_{3}\right.$ incompletely erupted in a female and non-erupted in a male). Assuming that mass farrow used to occur in March and April, the time of slaughter of these two animals fells on autumn.

\section{B. Horse bones from the Gnezdovo burial mounds}

A horse skeleton from the burial mound Ts-142, the specimen S-106950, ZM MSU (Fig. 2). It was found almost without accompanying equipment; archaeologists suggested that a neighbouring burial mound contained a grave of the warrior having had owned it (Andreeva, 1980).

As Avdusin et al. (1975; pp. 134-135) commented, a well-preserved horse skeleton lying on the right side was found at the bottom of a pit, with its head turned north-westerly. In the pit, the skeleton lied obliquely, with its head and neck shifted towards the vertebral 
Table 2. Composition of mammal remains from the "Pozhar 1" layer.

\begin{tabular}{|c|c|c|c|c|}
\hline Taxon & $\begin{array}{c}\text { Total } \\
\text { number of } \\
\text { specimens }\end{array}$ & $\begin{array}{l}\text { Number of } \\
\text { carbonised } \\
\text { specimens }\end{array}$ & Skeletal elements & $\begin{array}{l}\text { Size } \\
\text { class }\end{array}$ \\
\hline \multicolumn{5}{|c|}{ Mammals (unidentifiable more precisely) } \\
\hline Larger & 450 & 175 & $\begin{array}{l}\text { skull, teeth, ribs, vertebrae, scapulae, large cylindrical } \\
\text { bones }\end{array}$ & - \\
\hline Medium-sized & 37 & 20 & ribs & - \\
\hline \multicolumn{5}{|c|}{ Specimens identified to species } \\
\hline $\begin{array}{l}\text { Equus caballus, } \\
\text { horse }\end{array}$ & 2 & - & scapula (1), metatarsus ( 1 complete) & $s m, m$ \\
\hline $\begin{array}{l}\text { Bos taurus, } \\
\text { cattle }\end{array}$ & 184 & 20 & $\begin{array}{l}\text { skull (3), upper jaw (2), teeth (146, including } 17 \\
\text { complete), hypoglossal bones (2), lower jaw (7), } \\
\text { thoracic and lumbar vertebrae (4), rib (1), scapula (1), } \\
\text { metacarpals (3), pelvis (2), femur (1), articular tarsals } \\
\text { (2), metatarsals (8), phalanges } 1 \text { and } 2 \text { (2) }\end{array}$ & $s m, m$ \\
\hline $\begin{array}{l}\text { Capra hircus / } \\
\text { Ovis aries } \\
\text { goat / sheep }\end{array}$ & 39 & - & $\begin{array}{l}\text { lower jaw (2), teeth ( } 34 \text {, including } 4 \text { complete), vertebra } \\
\text { (1), scapula (1), femur (1) }\end{array}$ & $s m$ \\
\hline $\begin{array}{l}\text { Ovis aries, } \\
\text { sheep }\end{array}$ & 5 & 2 & horn-core & $s m$ \\
\hline $\begin{array}{l}\text { Sus domesticus, } \\
\text { pig }\end{array}$ & 99 & 29 & $\begin{array}{l}\text { skull (1), upper jaw (4), lower jaw (8), teeth ( } 60 \text {, } \\
\text { including } 5 \text { complete), ulna (1), femur (1), cannon bone } \\
\text { (5), metapodia (8), ankle bone (1), calcaneus (1), } \\
\text { phalanges (9) }\end{array}$ & $s m, m$ \\
\hline Total & 816 & 246 & - & - \\
\hline
\end{tabular}

Note: $(m)$ medium-sized and $(\mathrm{sm})$ small size classes of animals.

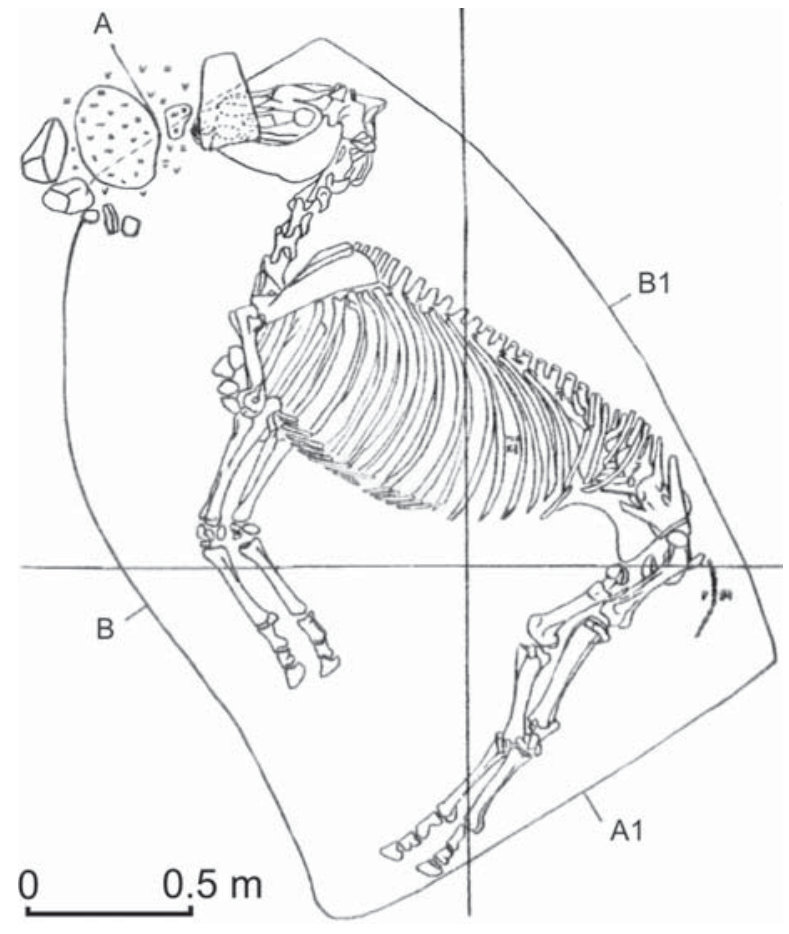

Fig. 2. Field map of the Ts-142 burial (after Avdusin et al., 1975). column. The skull was broken into a number of pieces. With the content of the pit being examined, accumulations of coal pieces (about $10 \times 5 \mathrm{~cm}$ ) were found at both sides of the cervical vertebrae. The fore legs were curved inside and positioned above the body at the inclined south-western wall of the pit. The hind legs were extended and also positioned above the body at the south-western wall of the pit. The horse skeleton was $160 \mathrm{~cm}$ long. A bronze plate was found between its ribs in the area of its belly surrounded by a decomposed organic matter.

This skeleton belonged to a 15-16-year-old stallion ("adult" after Andreeva, 1980). The bones were well preserved, greyish yellow, without a trace of charring; many of them were fragmented in the bed or in the course of extraction. In the skeleton, the following parts and elements were preserved:

(1) The cranial skeleton consists of 39 axial skull fragments and 9 mandibular fragments. The tooth rows are completely preserved and deserve more detailed description. Rudimentary P1 is absent. Horizontal grooves are observed on the lateral parts of crowns of almost all upper and lower teeth at the occlusal surface. They are especially well expressed on the external surface of molar rows of the both mandibular rami. The upper corner teeth are worn non-uniformly (Figs. 3A, 3B). Small wear facets are present on the upper internal 

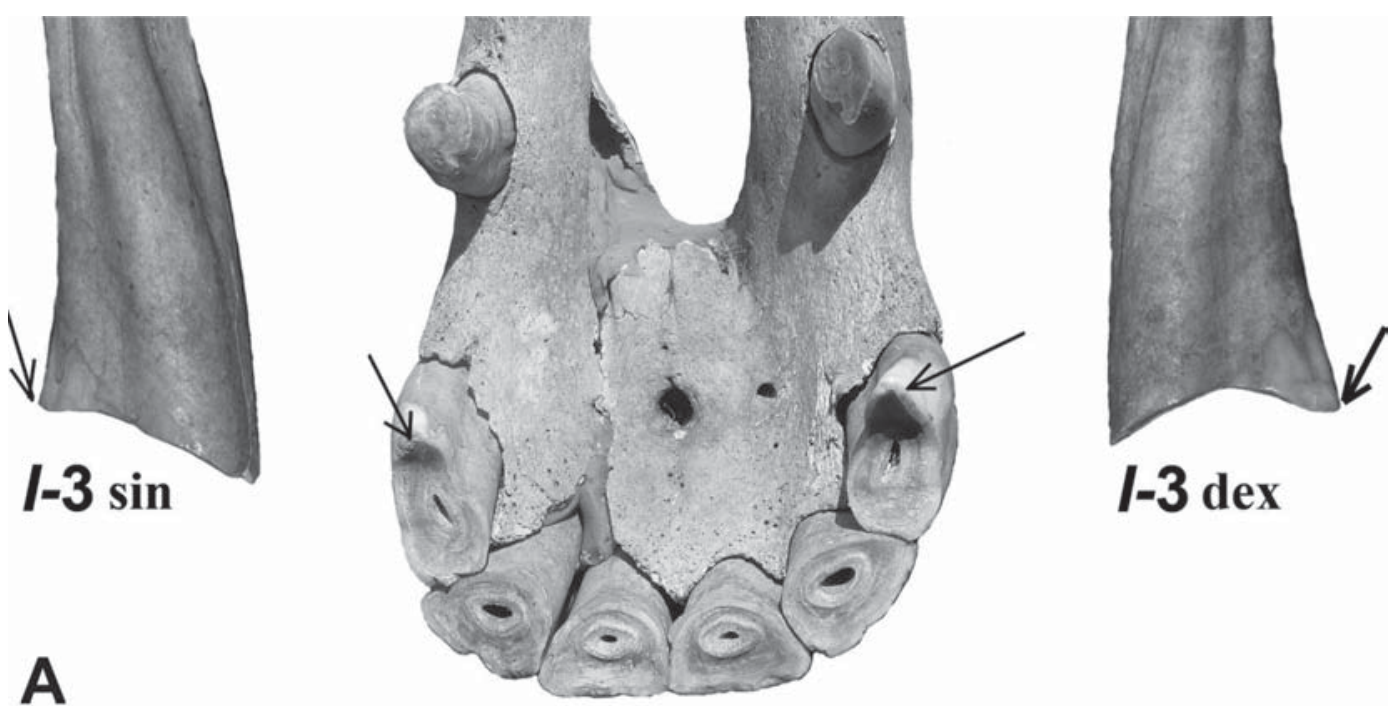

A

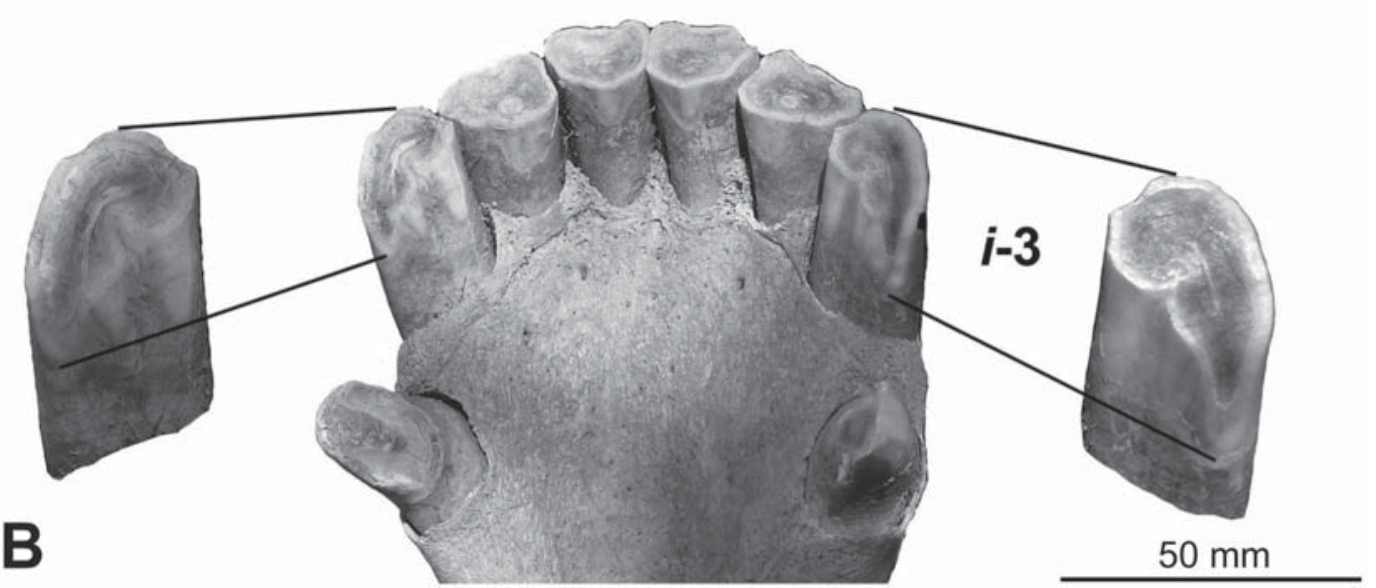

Fig. 3. Incisor and canine rows of stallion from the Ts-142 burial (ZMMU, no. S-106950), internal view: (A) upper teeth, $I$ 3 sin and $I-3$ dex magnified corner teeth (turned for approximately $90^{\circ}$ ), left $(\sin )$ and right (dex), respectively. Arrow indicates projection on the occlusal surface connected with malocclusion. (B) lower teeth. Magnified specimen displays a wear facet passing onto the posterior surface of corner teeth. On the right side this character is more strongly pronounced. Both figures show that canines are worn.

part of both lower canines. The upper canines are worn much more intensely, with smooth internally inclined wear facets at the level of the proximal quarter of these teeth. The upper anterior premolars $(\mathrm{P} 2)$ are worn sharply asymmetrically (Figs. 4-6). The right premolar is worn almost to its root. The lower anterior premolars are also asymmetrically worn. Thus, occlusal surface in the left p2 is situated at almost the same level as in all other teeth, and the crowns of upper and lower anterior premolars are almost equal in their height. At the same time, the posterior part of $\mathrm{p} 2$ projects 5-7 $\mathrm{mm}$ higher on its right side than its occlusal surface, and its crown is considerably higher than that of P2. Right $\mathrm{p} 2$ has traces of intravital microsplits, which are smoothed apparently by contact with the bridle bar;

(2) Three hypoglossal bone fragments;

(3) The vertebral column is almost complete (ex- cept for the caudal region): there are 7 cervical, 18 thoracic, 5 lumbar, 5 sacral (4 complete) and 1 fragmentary caudal vertebrae;

(4) The sternum (5 fragments);

(5) The ribs: 11 specimens (2 complete), including 5 left and 6 right; 10 fragments of distal cartilaginous parts of ribs;

(6) The pelvic bones and scapulae are morphologically completely preserved, but were fragmented during extraction;

(7) Large cylindrical limb bones are completely preserved; the left humerus consists of several fragments;

(8) Bones of the distal limb regions are completely preserved, except for the sesamoid bones.

Tables 3 and 4 include measurements of teeth and bones of this specimen. 

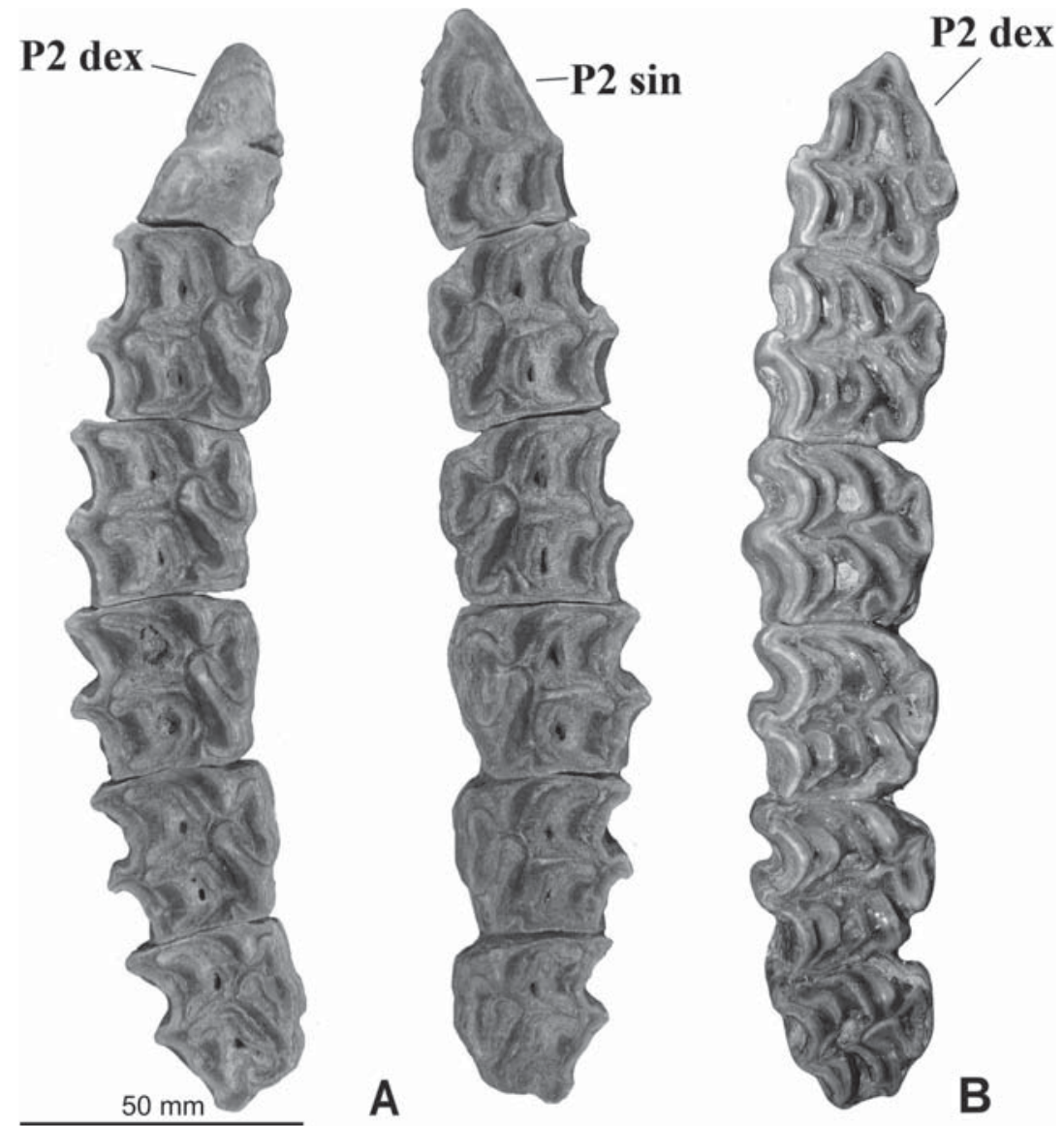

Fig. 4. Upper tooth rows of horses, occlusal view: (A) stallion from the Ts-142 burial (ZMMU, no. S-106950); asymmetrical wear of anterior premolars against bridle bar, seen on the left anterior premolar and well pronounced on the right side. (B) upper tooth row of living mustang, without wear facets caused by harness (ZMMU, no. S-186105).

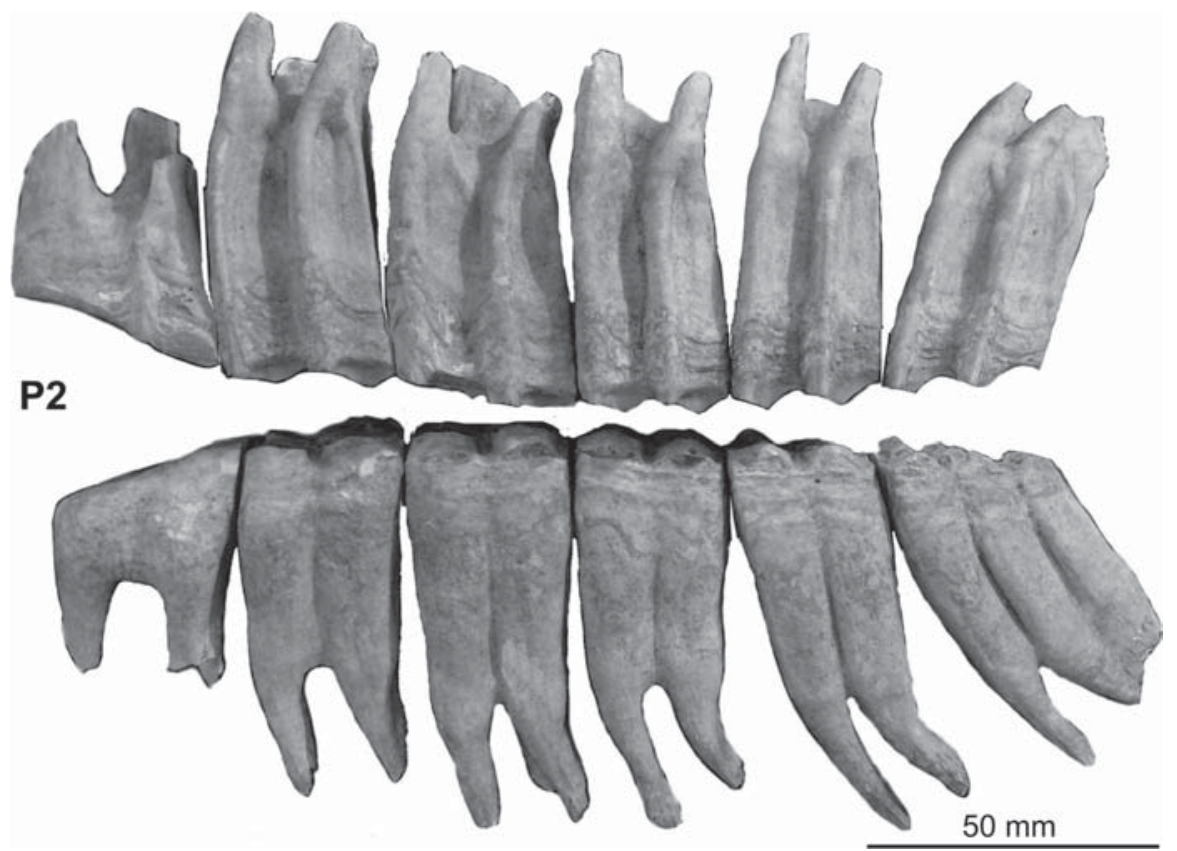

Fig. 5. Left tooth rows of stallion from the Ts-142 burial (ZMMU, no. S-106950), external view. Upper and lower anterior premolars symmetrically worn against the bridle bar. 


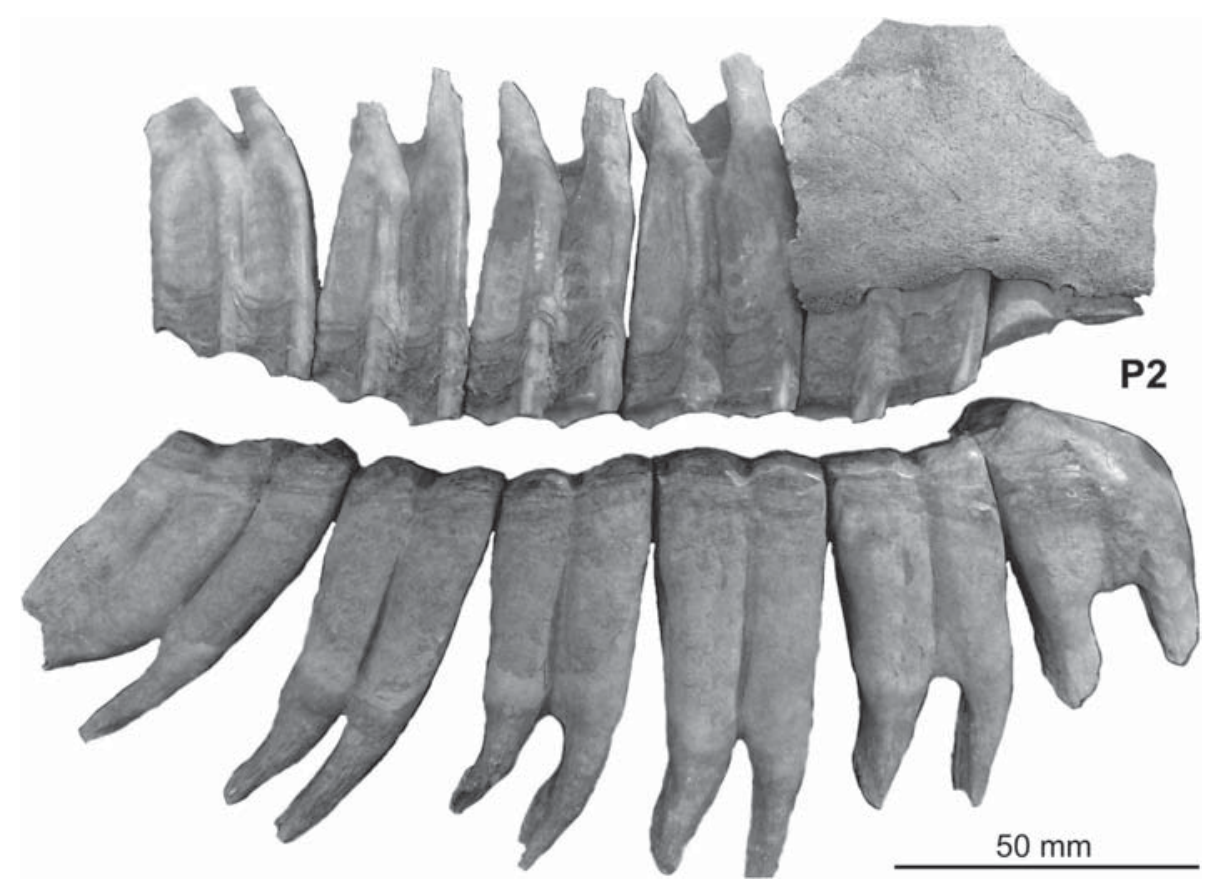

Fig. 6. Right tooth rows of stallion from the Ts-142 burial (ZMMU, no. S-106950), external view. Upper and lower anterior premolars strongly asymmetrically worn against the bridle bar.

Table 3. Measurements of the horse teeth from Gnezdovo (right / left mandible).

\begin{tabular}{|c|l|c|c|}
\hline \multirow{2}{*}{ Measurement (mm) } & \multicolumn{2}{c|}{ Burial mound } \\
\cline { 3 - 4 } & S-106950 & S-106951 \\
\cline { 3 - 4 } & ZM MSU & ZM MSU \\
\hline & Upper cheek tooth & \multicolumn{2}{c|}{} \\
\hline 1 & P2 tooth length & $30 / 41.5$ & $-/ 36.7$ \\
\hline 2 & P2 maximal breadth & $19 / 24$ & $-/ 24$ \\
\hline 3 & P3 length of the protocone & $-/ 9.2$ & $-/ 8.5$ \\
\hline 4 & P3 tooth length & $27 / 29.6$ & $-/ 27$ \\
\hline 5 & P3 maximal breadth & $30.5 / 27$ & $-/ 27$ \\
\hline 6 & P3 length of the protocone & $11.8 / 10.2$ & $-/ 10$ \\
\hline 7 & P4 tooth length & $27.3 / 30.7$ & $-/ 27.4$ \\
\hline 8 & P4 maximal breadth & $27.9 / 27$ & $-/ 26$ \\
\hline 9 & P4 length of the protocone & $12 / 11$ & $-/ 11$ \\
\hline 10 & M1 tooth length & $25.7 / 25.4$ & $-/ 23$ \\
\hline 11 & M1 maximal breadth & $26.5 / 27$ & $-/ 24.7$ \\
\hline 12 & M1 length of the protocone & $13.2 / 13$ & $-/ 12$ \\
\hline 13 & M2 tooth length & $26.5 / 26.2$ & $-/ 23.8$ \\
\hline 14 & M2 maximal breadth & $25 / 25$ & $-/ 26$ \\
\hline 15 & M2 length of the protocone & $14.2 / 13.2$ & $-/ 13.2$ \\
\hline 16 & M3 tooth length & $30.7 / 30.5$ & $-/ 27$ \\
\hline 17 & M3 maximal breadth & $23.5 / 22.7$ & $-/ 22.7$ \\
\hline 18 & M3 length of the protocone & $13.8 / 14$ & $-/ 14.2$ \\
\hline 19 & Length of the tooth row & $174.5 / 180.2$ & 161.2 \\
\hline 20 & Length of the premolar row & $88 / 100$ & 90 \\
\hline 21 & Length of the molar row & $82 / 82.5$ & 78 \\
\hline & & & \\
\hline
\end{tabular}

\begin{tabular}{|c|c|c|c|}
\hline \multirow{2}{*}{ Measurement (mm) } & \multicolumn{2}{c|}{ Burial mound } \\
\cline { 3 - 4 } & S-106950 & S-106951 \\
\cline { 3 - 4 } & ZM MSU & ZM MSU \\
\hline & Lower cheek tooth & \multicolumn{2}{c|}{} \\
\hline 1 & p2 tooth length & $34.5 / 30.5$ & $31.5 / 29.2$ \\
\hline 2 & p2 maximal breadth & $14.8 / 17.2$ & $17.4 / 14.8$ \\
\hline 3 & p2 length of the postflexid & $-/ 16.5$ & $17.5 / 18$ \\
\hline 4 & p3 tooth length & $27.8 / 28.8$ & $25.1 / 24.3$ \\
\hline 5 & p3 maximal breadth & $15.7 / 19.7$ & $20.1 / 17$ \\
\hline 6 & p3 length of the postflexid & $13 / 12$ & $12.8 / 12.4$ \\
\hline 7 & p4 tooth length & $27.5 / 27.5$ & $25.1 / 25$ \\
\hline 8 & p4 maximal breadth & $19.2 / 19.8$ & $17.9 / 19.2$ \\
\hline 9 & p4 length of the postflexid & $11 / 10.5$ & $12.5 / 12$ \\
\hline 10 & m1 tooth length & $26 / 25.7$ & $22.4 / 22.8$ \\
\hline 11 & m1 maximal breadth & $17.2 / 17.7$ & $15.5 / 20.1$ \\
\hline 12 & m1 length of the postflexid & $7 / 7.02$ & $8.2 / 7.4$ \\
\hline 13 & m2 tooth length & $26.5 / 25.7$ & $23 / 23.2$ \\
\hline 14 & m2 maximal breadth & $15.6 / 16$ & $16.9 / 17.2$ \\
\hline 15 & m2 length of the postflexid & $8.2 / 7.7$ & $7.2 / 7.6$ \\
\hline 16 & m3 tooth length & $34.7 / 34.7$ & $29.1 / 29.2$ \\
\hline 17 & m3 maximal breadth & $14.3 / 14$ & $12.5 / 14.1$ \\
\hline 18 & m3 length of the postflexid & $11 / 10.6$ & $8.6 / 9.7$ \\
\hline 19 & m3 length of the talanoid & $8.5 / 9$ & $7 / 7$ \\
\hline 20 & Length of the tooth row & $176.2 / 176$ & $160 / 158$ \\
\hline 21 & Length of the premolar row & $91.2 / 91.2$ & $84 / 82.4$ \\
\hline 22 & Length of the molar row & $86 / 88$ & $78 / 78$ \\
\hline & & & \\
\hline
\end{tabular}




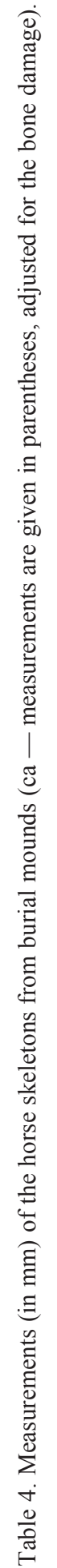

\begin{tabular}{|c|c|c|c|c|c|c|}
\hline 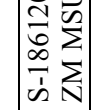 & $\mid \begin{array}{l}0 \\
\dot{0} \\
\dot{f}\end{array}$ & $\begin{array}{l}\infty \\
\dot{0}\end{array}$ & $\begin{array}{l}\tilde{J} \\
\tilde{S}\end{array}$ & $\frac{n}{a}$ & f & 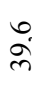 \\
\hline 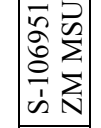 & $\mid$\begin{tabular}{|cc}
0 \\
$\vdots$ \\
0 \\
0 \\
0 \\
0
\end{tabular} & I & & 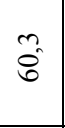 & m & $\underset{\infty}{\infty}$ \\
\hline 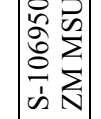 & $\left|\begin{array}{l}\infty \\
0 \\
0 \\
0 \\
0\end{array}\right|$ & & 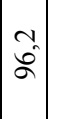 & $\stackrel{\cong}{ }$ & fo & $q$ \\
\hline
\end{tabular}

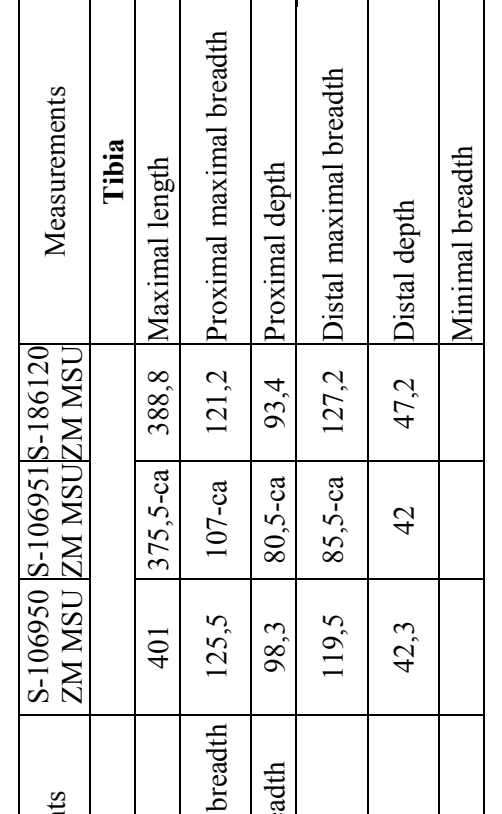

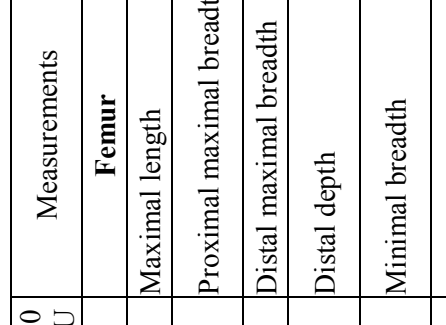

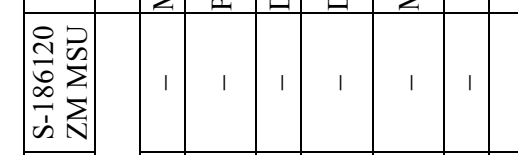

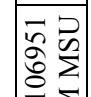

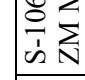

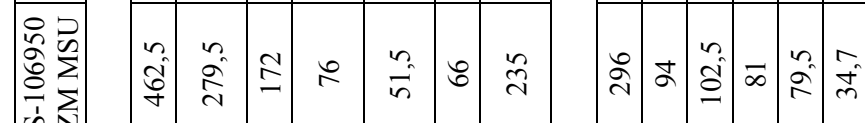

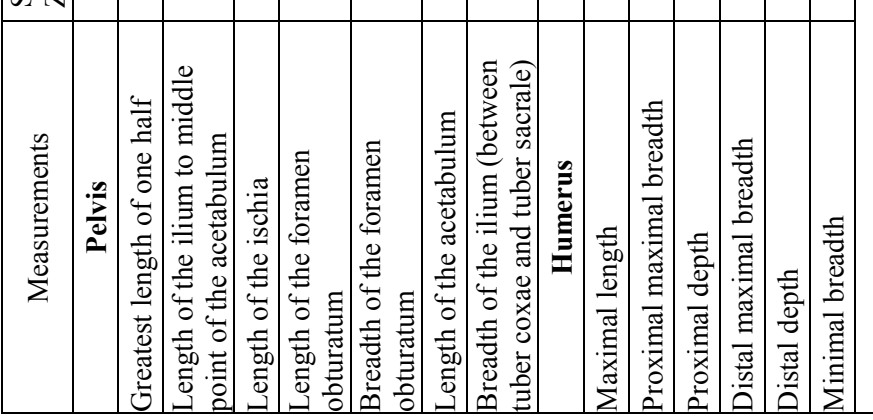

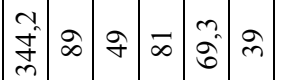

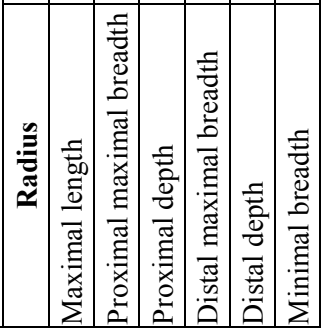

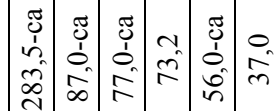

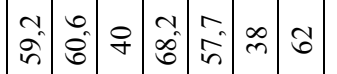

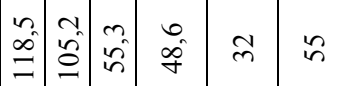

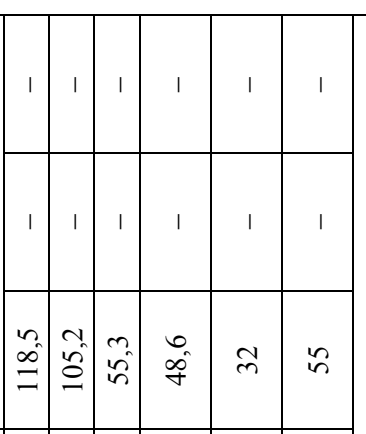

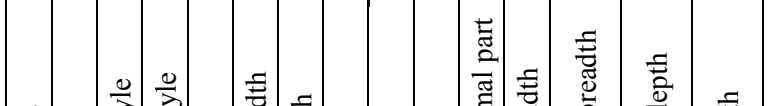

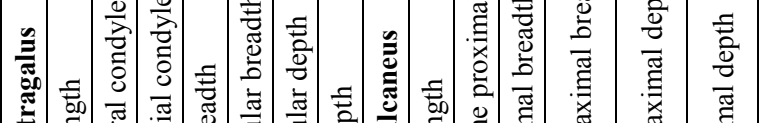

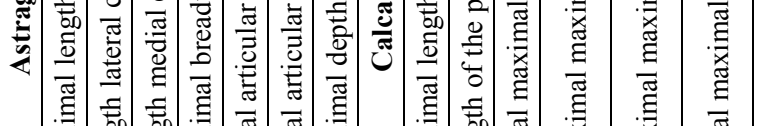

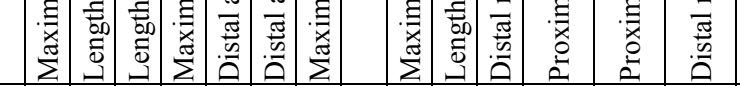

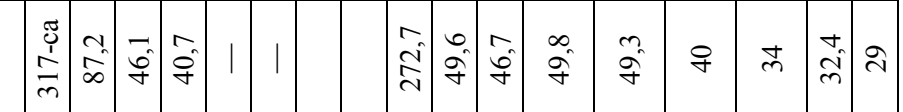

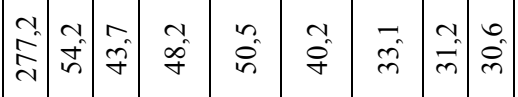

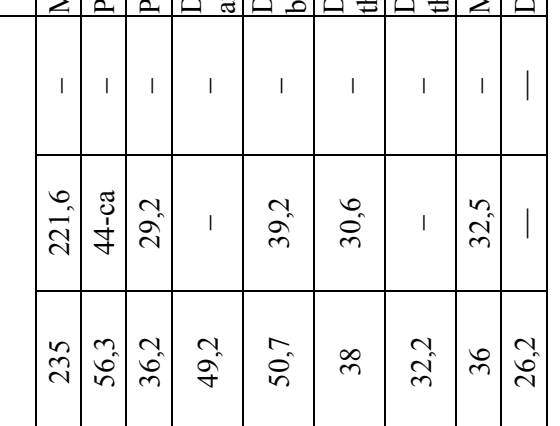

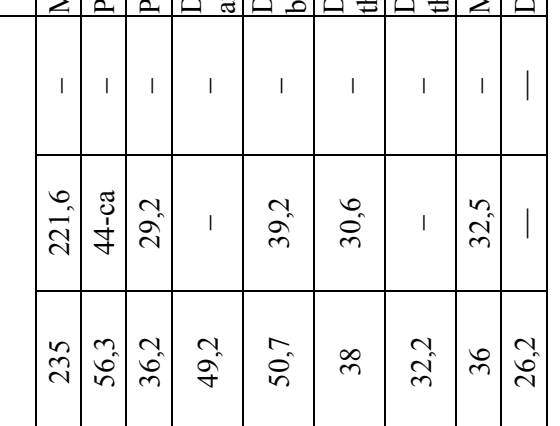

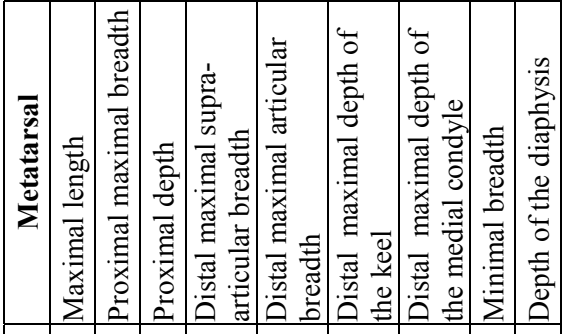

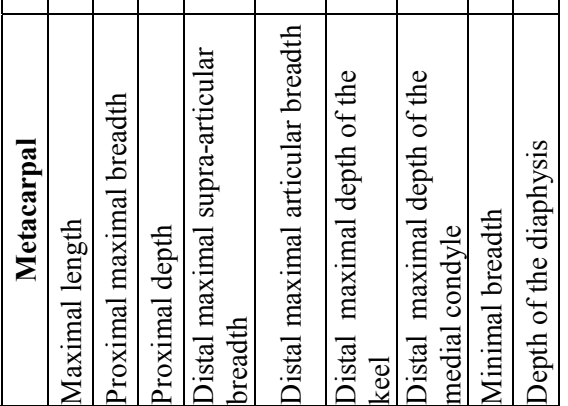




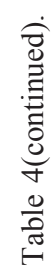

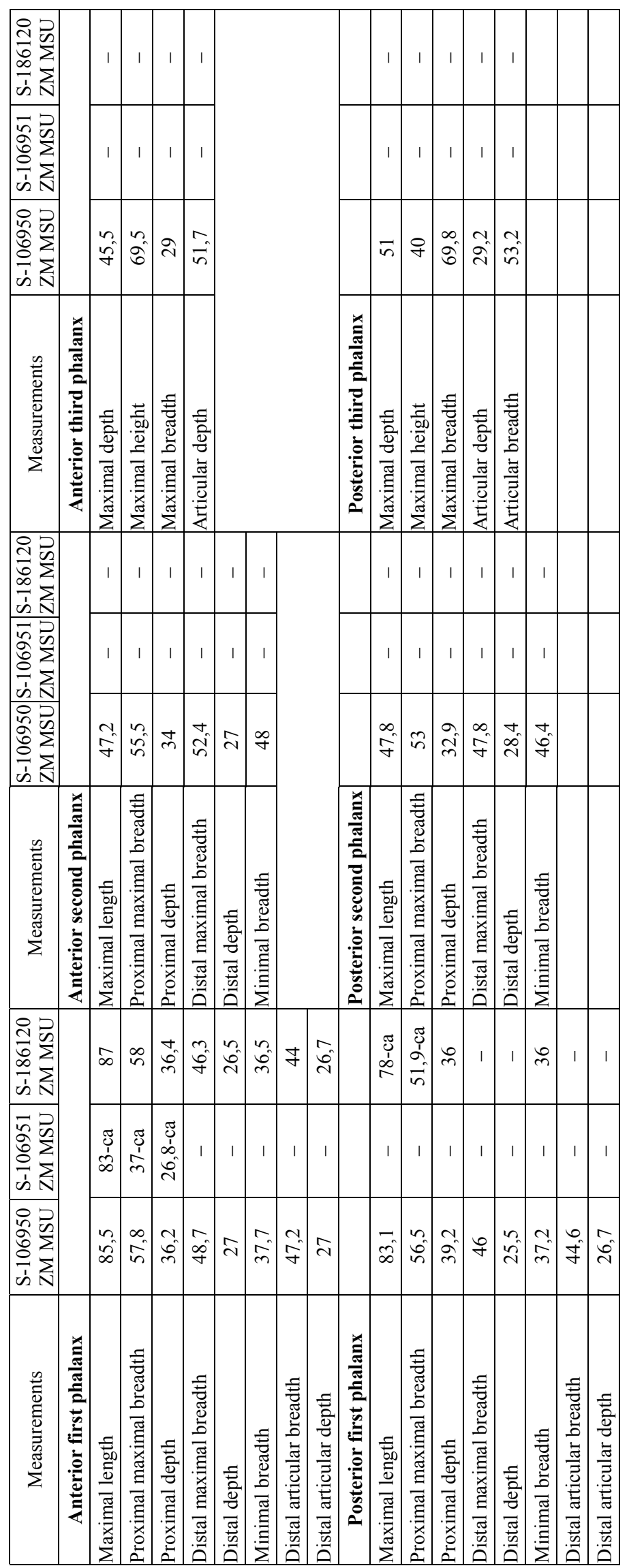




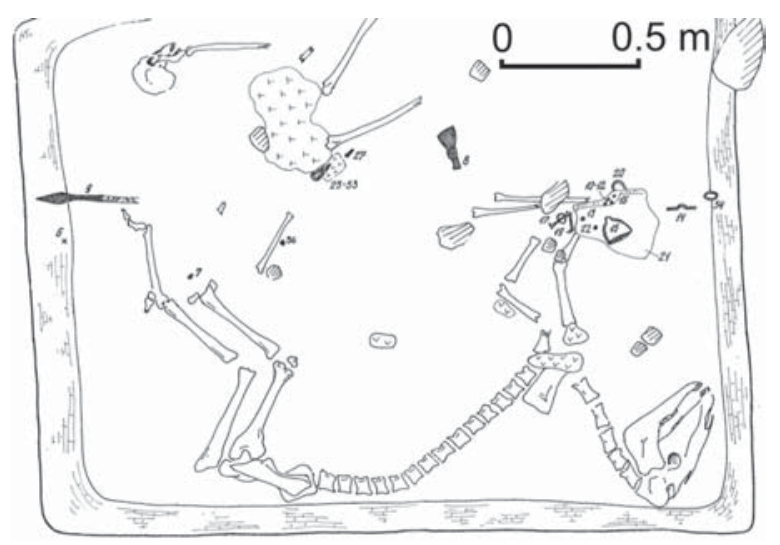

Fig. 7. Field map of the Ts-191 burial (after Avdusin et al., 1976).

A horse skeleton from the burial mound Ts-191 (specimen S-106951, ZM MSU) was found along with a human skeleton.

According to the Field Report (Avdusin et al., 1976), the funeral pit is rectangular, $225 \times 275 \mathrm{~cm}$, positioned in the centre of the burial mound, it cuts a fire pit. The funeral pit is bordered by a 5-20-cm-wide band rich in ash. At a depth of 235-240 cm, decomposed wood 10 $15 \mathrm{~cm}$ thick borders the pit alongside its perimeter. The human skeleton was in the northern part of the pit, with its head positioned northerly. The well preserved horse skeleton was in the southern part of the pit, to the right of the human skeleton (Fig. 7), oriented eastwards. The horse was put on its right side, with its fore and hind legs slightly bent. Fore leg bones have small pieces of charred wood. Close to the bend of fore legs, there were remains of a wooden saddle covered with leather using bronze rivets. An iron bit and stirrups were found near the saddle and a bridle was under the saddle (Avdusin et al., 1976, pp. 119-123).

The both skeletons are very poorly preserved, with most of the bones being fragmented in the bed or during extraction. Completeness of external part of the compacta and direct evidence of charring are observed on almost all bones (Fig. 8); in many specimens compacta continues to crack and fall off.

The horse skeleton in question includes the following pieces:

(1) The skull consisting of eight fragments. The left upper row of cheek teeth is preserved in the jaw. Rudimentary P1 is absent. The occipital condyles and basal part of the occipital both display distinct traces of charring. Dentine of the upper incisors crumbles easily, but the teeth retain their shape due to enamel elements. The mandible is preserved almost completely. Traces of charring are particularly well pronounced on the left side; the ascending ramus of the lower jaw was burnt almost completely; the dentaries are distorted, so that the alveolar edge diverged from the tooth row. Lower incisors are strongly damaged, while lower cheek tooth rows are complete. The anterior parts of the occlusal

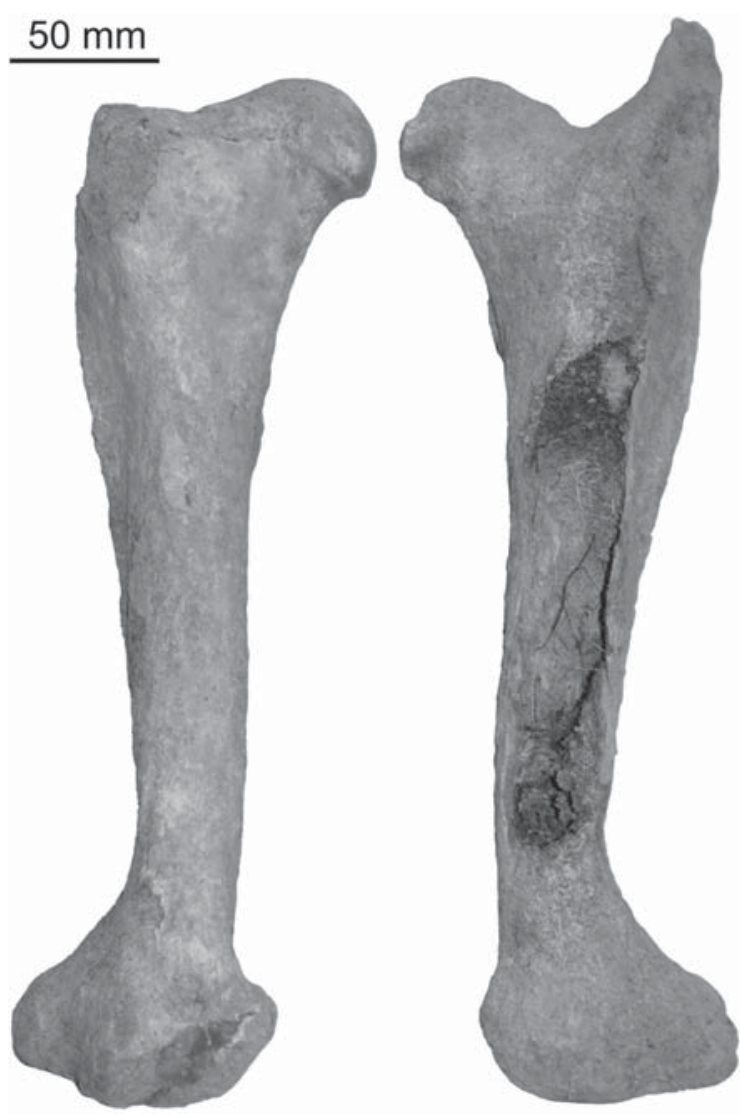

Fig. 8. Femora of stallion from the Ts-191 burial (ZMMU, no. S-106951), anterior view. Left femur (on the right in the figure) displays charred internal part in the sites where compacta is absent, while damaged compacta lacks a trace of charring. In the right femur (on the left in the figure) compacta is slightly damaged, traces of charring are weak.

surface of both upper and lower P2 show a specific even wear, which is more intensive than in the other cheek teeth. The $\mathrm{p} 2$ is worn to a much greater extent than P2, which is apparently caused by constant friction against metal elements of the harness. A significant wear is although marked on the upper canines. The internal surface of the dentary is well preserved, without any trace of the fire. Table 3 shows the tooth measurements.

(2) The vertebral column is represented by 31 fragments, all with charring traces.

(3) The humeri ( 2 pieces) show traces of charring throughout the surface, which are intense in the middle of the diaphysis.

(4) The forearm bones. The ulnae are absent, while both radii are present. The right bone is represented by an external part only, while its left counterpart has its diaphysis burnt out.

(5) The pelvic bones are almost complete, with both rami preserved. The ilia are charred externally, which is particularly well pronounced on its left side.

(6) Both femora are preserved, the left bone is charred (Fig. 8). 


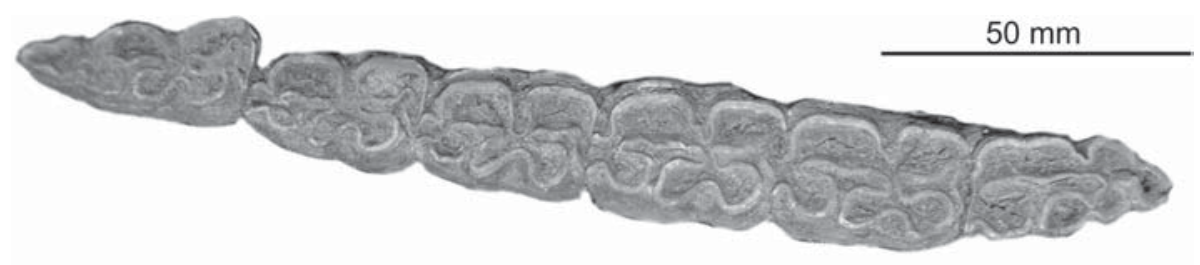

A

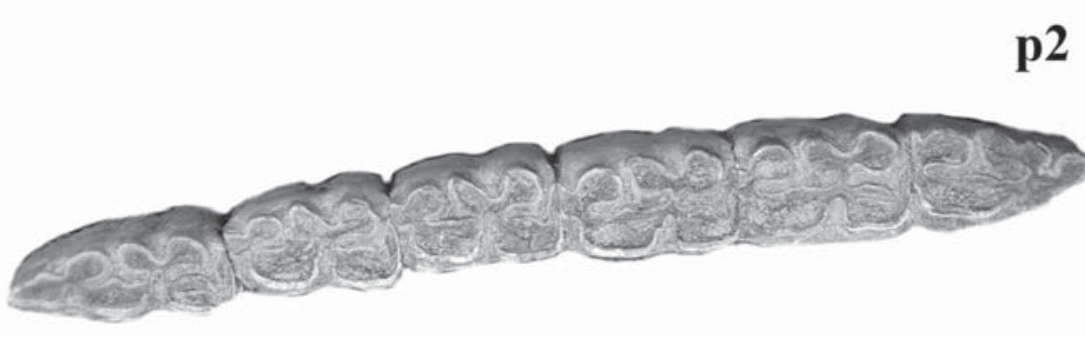

p2

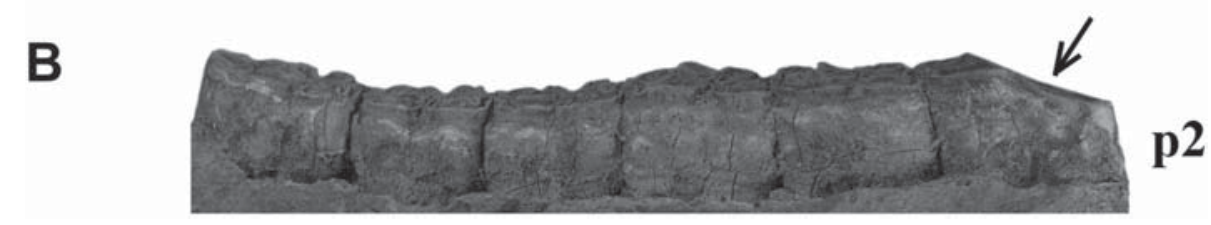

Fig. 9. Lower tooth rows of stallion from the Ts-191 burial (ZMMU, no. S-106951): (A) view from above; (B) right ramus, external view. Arrow indicates oblique wear of the anterior premolar against the bridle bar.

(7). Both cannon bones are preserved; the middle part of the right bone and upper part of the diaphysis of the left bone are charred.

(8) The metapodials. The metacarpal is only preserved on the left side, with the middle part of the diaphysis charred. Both metatarsals are preserved, strongly charred in the diaphyseal part for half of the bone depth; small sites of intact compacta on the articular surfaces are present.

(9) All articular bones of the carpus and tarsus (7 specimens) display traces of charring. The ankle bones ( 2 specimens) are almost complete; the calcaneus is single, strongly charred.

(10) The patella (1 specimen) is strongly charred.

(11) The first phalanges (probably one anterior and one posterior) are strongly charred in the middle and lower parts, with better preserved proximal articular surfaces.

Table 4 show these bone measurements.

A horse skeleton from the burial mound Ts-255 (specimen S-186120, ZM MSU). Horse and human skeletons were found in a common pit, which cut the fire pit under the mound (Fig. 10). The pit is bordered by a dark ash ring $(30-35 \mathrm{~cm}$ wide) and filled with sand impregnated with ash and coal particles. The human skeleton was just partially preserved, oriented westerly. The horse skeleton was to the right of the human skeleton. Avdusin et al. (1978, pp. 55-57) observed that the former was completely preserved, oriented south-westerly. The horse lays on its right side, with its fore and hind legs bent towards the trunk. Pelvic bones of the horse were displaced to the right side, and the right hind leg was under pelvic bones. The horse harness found in the burial includes a two-part ring bit with cheek pieces, iron stirrup and buckles for belts.

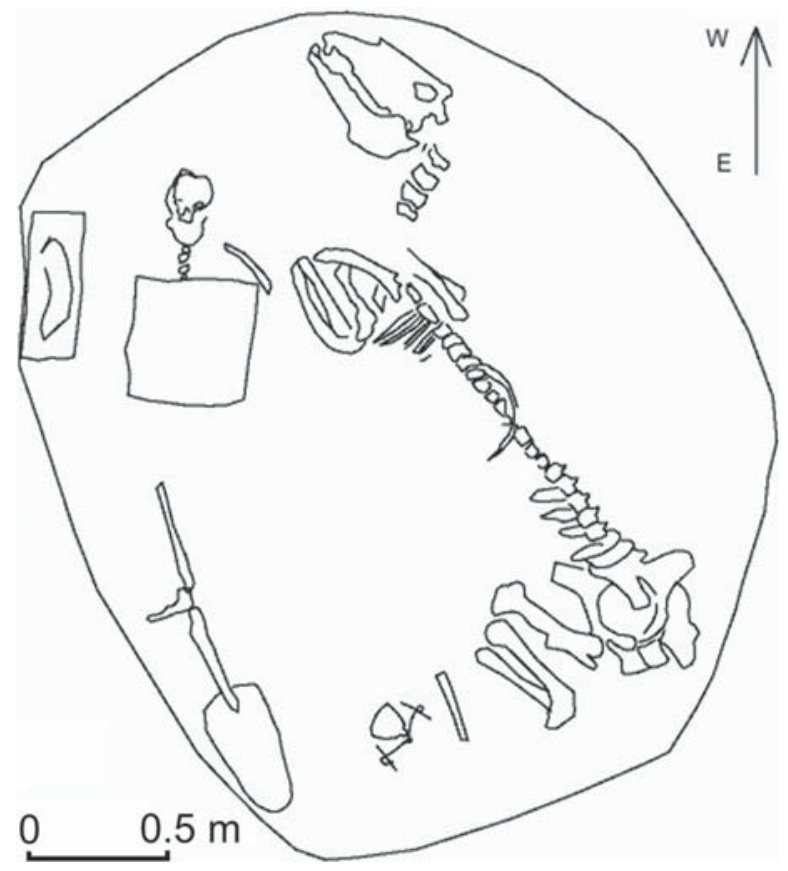

Fig. 10. Field map of the Ts-255 burial (after Avdusin et al., 1978). 
Because of lack of the skull and the pelvic bones, it is impossible to determine exact individual age and sex of this horse. However, judging from the fusion between epiphyses and diaphysis of the postcranial bones, it was an adult.

In the Field Report (Avdusin et al., 1978) charring was not marked. The burial is referred to the chamber type and regarded as an inhumation. However, our reexamination of the horse skeleton revealed undoubted traces of a thermal effect distributed non-evenly. Some of them underwent a greater disruption than others; and even different areas of the same individual bones vary strongly in preservation. The right femur and right cannon bone are well preserved. Large cylindrical bones of the fore limbs (humerus, radius, metacarpals) are however poorly preserved. Apart from the fire, preservation of the bones was influenced by soil active substances: in the metatarsals, left cannon and in some other bones, the compacta surface shows distinct rough microsculpturing (resulting from corrosion by acids).

In the horse skeleton, the following bones were identified:

(1) The cranial bones (37) are represented by small fragments of the otic, occipital, zygomatic bones, zygomatic process of the frontal, braincase, and three fragments of the left ascending mandibular ramus (a part of the articular process).

(2) In the vertebral column, the following were recognised:

- Five strongly damaged cervical vertebrae (except for the epistropheus) and 1 fragment. The bones are poorly preserved, easily crumbled, usually fragmented, but some fragments are possible to put in natural position to reconstruct particular bones;

-16 thoracic vertebrae. Those identified as the $1 \mathrm{st}$ and 4-16th show the effect of high temperature on the left side, with expanding sometimes, at the vertebral centrum base, onto the right side. Almost all neural spines are disrupted, with the left lateral spine being preserved in the three first thoracic vertebrae;

- Four (anterior) lumbar vertebrae. In the first of them, the neural spine is disrupted. The lateral processes are preserved on the right side and disrupted on the left side in all vertebrae.

- Three caudal vertebrae.

The articular facets and vertebral centra lack any trace of diseases or other individual features, except for the centra of the last two thoracic vertebrae, which show distinct age changes.

(3) The ribs are represented by 35 fragments, including 11 articular fragments of right ribs and 4 articular fragments of left ribs; 11 rib fragments have distinct traces of fire.

(4) The scapulae (4 fragments). The right one is represented by two large fragments of the articular part, with its compacta strongly damaged (charred). The left one consists of two very poorly preserved charred fragments.

(5) The humeri (two bones) and one small fragment of the lesser tubercle of the left bone. The left humus is complete, very poorly preserved. The colour of intact surface is whitish yellow; more than half of the bone extent lacks an external compacta layer and is dark brown, up to black due to charring. A split of this bone indicates that the compacta blackening varies in depth in its different portions and the charred layer overlies a light intact compacta layer. The thermal effect is most pronounced on the entire posterior surface of the bone (which lacks an external compacta layer) and on its distal epiphysis, which is considerably disrupted. However, an anterior part of the bone, where compacta is not completely lost, also shows a charred surface. The right humerus is satisfactory preserved, with whitish yellow compacta. The proximal part is lost on the anterior side up to one-third of the bone extent. In contrast to the left bone, distinct charring traces are absent, but spongy tissue in the broken site is much darker than compacta; it is dark brown. The external compacta layer is disrupted on the internal and posterior surfaces of the distal bone part, as in other bones of the skeleton that underwent thermal influence. The same is true for the proximal part, particularly for the internal and posterior surfaces of the epiphysis.

(6) The ulnae (two bones) are strongly damaged. The left bone retains its articular part and a tubercle fragment. The thermal effect is observed on the tubercle and the posterior part. In the right bone, the tubercle is not preserved and the proximal part is charred.

(7) The radii (two bones). In the anterior part of the left bone, the external part of compacta is almost completely disrupted, exposing the underlying charred layer (which extends deep into the bone for half of the compact layer thickness). The lower third of the anterior bone surface is most strongly charred. It is to be noted that initially the thermal traces were apparently hidden under the upper compacta layer, which lacks any trace of the thermal influence. The right bone was affected by high temperature to a lesser extent and these traces are mostly hidden by the external layer which looks intact. Fragments of compacta exposed to the thermal effect are on the medial, lower anterior and proximal parts of the bone.

(8) The splint bones (four pieces). Two hind bones are almost complete. In one posterior and in one anterior bones, their proximal parts are not preserved.

(9) The femur (two bones). The right bone is satisfactory preserved (in particular, in the diaphysis), it is charred; its greater trochanter lacks compacta. The left bone is poorly preserved, with a rough surface of the diaphysis (corroded); its medial condyles, lesser and third trochanters are disrupted. The effect of high temperature is not observed on the surface or inside of the bone.

(10) The cannon bones (two specimens). In the left bone, compacta is strongly disrupted on the external surface of the proximal joint. The diaphysis has a rough microsculpturing (corroded compacta). The right bone is better preserved. Traces of thermal influence are distinct in the distal epiphysis (internal part); its proximal epiphysis has slight injuries. 
(11) The metacarpals (two specimens). The left bone shows strong traces of fire (charring under the compact part); a charred bone tissue is exposed where the external part of compacta was lost. The proximal part is not preserved. The greatest damage is observed on the posterior and partly internal surfaces of the bone. The right bone is strongly charred (almost burnt); compacta is completely disrupted within the anterior lower part and internal (lateral) surface of the bone; charring is observed on the internal side under the proximal articular surface.

(12) The metatarsals (two specimens) are almost complete. In the right bone, the thermal effect is distinct on the anterior surface (insignificant) and on the lateral surface under the proximal epiphysis. The entire surface of the diaphysis of the left bone has a rough microsculpturing (corroded compacta); compacta becomes more even close to the epiphyses.

(13) The first phalanges (three specimens). The right anterior phalanx is almost complete. In the left anterior bone, the distal part (thermal effect is evident; external compacta layer is lost) and the upper posterior part of the proximal articular surface are disrupted. In the left posterior bone, the entire posterior surface and the distal part are disrupted.

(14) The second phalanx (one fragment without compacta). ment).

(15) The third phalanx (one strongly disrupted frag-

(16) The patella (one specimen). The external compacta layer is disrupted on one side, exposing a charred bone layer.

(17) The carpals and tarsals (nine specimens). The ankle bone and the calcaneus are strongly charred; the upper part of the calcaneal tubercle is not preserved; the posterior edge of the bone body, ridges of the pulley and posterior surface of the ankle bone are charred. The left ankle bone and left calcaneus are better preserved; the medial ridge of the pulley and posterior part of the bone are only slightly charred. The calcaneal tubercle is disrupted.

Table 4 shows bone measurements.

\section{Results and discussion}

\section{A. Horse bones from the settlements of Gnezdovo}

In the osteological collection from the settlements of Gnezdovo, proportion of the horse specimens is relatively small, which is evident from the materials collected at different periods. Thus, in a sample of 416 mammal specimens extracted in 1967 from the western part of the settlement of the site and identified to the species level, only 5.5\% remains belong to the horses (Ermolova, 1967). In later samples from the Central hillfort, the proportion of the horse bones was $10.3 \%$ and, in the eastern part of the ancient settlement of
Gnezdovo, it was 4.2\% (Andreeva, 1980). However, it is not quite clear from which assemblage (cultural layer, pit or construction) these remains originated, which would be important for interpretation of these materials. In the Horizon 5 of the floodplain settlement of Gnezdovo (collected by V.V. Murasheva in 1999-2001), only $4.8 \%$ (25 specimens) remains of domestic animals were those of the horses. They include cranial and mandibular fragments, teeth, vertebrae, ribs, and fragments of large cylindrical bones. Such a composition of the remains, along with the absence of small limb bones, is apparently due to a small sample size. The specimens belong to mature animals, some of them bearing traces of cutting and biting.. This feature was emphasised already by Andreeva (1980), who commented that the horses had been of great importance as a combat resource and probably draft animals, so only animals that had lost working ability were slaughter (for food). A small proportion of the horse specimens was also observed in the sample from the "Pozhar 1" layer.

In some pits and constructions of Gnezdovo, however, the proportion of the horse remains among mammal specimens may deviate strongly from the average to either much higher or lower values (Kirillova, 2007). Interpretation of composition and origin of the horse bones may be beyond the scope of alimentary use of these animals. Apparently, a record of such kind orginated from the "Nastil 2" complex of the floodplain settlement. A specific composition of mammal remains (mostly skull fragments of adult horse, cattle and pig, each represented by a sole individual) suggests purposeful burial in this site. Similar "storages" are well known from excavations in Novgorod, Suzdal and other medieval Russian cities. They are usually regarded as sacrifices for successful building, a tradition retained from the pagan time and widespread in different peoples and different historical epochs. The position of skulls (heads) of domestic animals in such a burial or even dog carcasses at the base of particular buildings suggests a pagan rite, intended for guarding buildings and builders against the evil spell (Sedov, 1957; Sedova \& Belen'kaya, 1981; Sedov \& Sedova, 1983). The horse skull (head) was the most traditional sacrifice in this case.

Taphonomic features of bones from the "Pozhar 1" layer (a floodplain part settlement of Gnezdovo) seem rather important for treating not only this layer, but also burial mounds. Bones that underwent the influence of the fire are divided into three groups:

(1) Burnt to whiteness (calcined) due to the effect of the strongest fire.

(2) Charred to blackness due to effect of a lower temperature flame.

(3) "Baked" bones which underwent "slow heating" (for example, by coals that did not provide open flame). Another probable situation may be the absence of direct contact with the fire source. This occurs when an object is isolated from the fire by a non-combustible layer (for example, soil) or lies at a distance. 
It is difficult to reconstruct events that occurred several centuries ago in Gnezdovo. However, a strong fire established by different methods in the layer named "Pozhar 1" could affect not only buildings, but also bone remains that were already in the ground, in the cultural layer.

The above types of thermal effects on the bone matter are also observed in the specimens from burial mounds considered below.

\section{B. Horse skeletons from burial mounds}

A horse skeleton from the burial mound Ts-142. Stallion bones display a number of features specific to this animal. They are divided into three groups: (1) agedependent, (2) resulting from the use of the saddle ("professional") and (3) caused by various other factors.

The first group comprises the following characteristics:

- Intravital degradation of compact bone matter, which is particularly well pronounced on the distal articular pulleys of the humeri;

- Excessive porosity of bone tissue in the internal part of the cervical vertebral corpora (in the spinal canal);

- "Loosening" of compact matter, with sharp expansion of nutrient foramen up to $3-5.3 \mathrm{~mm}$ on the posterior lower surface of os carpi intermedium, which is symmetrical on both fore limbs;

- Increase in nutrient foramina on two sides of the posterior thoracic vertebrae and in the calcaneus, ankle bones and first phalanges (signs of osteoporosis);

- Disruption and corrosion of the articular surface, slight smoothening resulting from sliding and friction of bones against each other on the articular facets of the ankle bone and calcaneus and disruption of compact matter in tarsal 4, which is usually caused by imperfection of synovial fluid due to friction against neighbouring bones in the joint (arthrosis).

The above characters of stallion bones from burial mound Ts-142 could have resulted from natural agedependent changes. This also concerns the fusion of splint bones with metacarpals on the medial side.

The second group of bone features witnesses intense use of the saddle. They comprise the well-developed tubercles for attachment of ligaments on the lateral surface of phalanges 1, which result from increased locomotor load, and the state of dentition. The arthrosis in the joints of the distal limb regions is possibly also caused (or intensified) by the horse use as a working animal. The most prominent characters of this group concern the dental system.

The premolars. It is evident that the anterior premolars of the stallion from the burial Ts- 142 were worn due to constant contact with a high-strength element of the harness, i.e. its metal bridle bar. This is usually observed in lower teeth (Antony \& Brown, 1989; Bendrey, 2007). However, in this case, wear is also mani- fested on the upper anterior premolars. Note that, in this burial, any harness elements were not found, though they occur in other burial mounds of Gnezdovo.

A sharp asymmetry of wear facets on the upper anterior premolars may result from an individual feature of this animal (a habit of "gnawing at iron element" primarily on the right side, which could have developed during training) and the manner of riding characteristic of its horseman. The latter may be explained, for example, by a habit of the horseman to stop a horse turning it to the right or predominant use of his right arm. As a rule, anterior premolars of a riding horse are rather uniformly worn against the bridle bar; in particular, this is observed in a stallion from the burial Ts-191 (see below) and in the living horses.

The incisors. These teeth usually escape contact with the harness elements and non-uniform wear of these teeth is usually caused by the horse misbehaviour (for example, it possibly used to gnaw at certain objects) or malocclusion (Korneven \& Lesbr, 1932). In this case we deal with malocclusion, since the wear facets extending onto the posterior side of both lower corner teeth (Fig. 3B) are accompanied by projections on the posterior part of the occlusal surface of the upper corner teeth (Fig. 3A). Occlusion of other upper incisors and all lower incisors is even (Fig. 3).

The third group includes characters which origin is difficult to derive from a particular main factor. In this case we deal with pathologies in two regions of the vertebral column. The 4th posterior thoracic vertebra (that is 15th) has an excessively strongly developed metapophysis on its right side, which is directed along the vertebral column axis (Fig. 11). Lumbar vertebrae 3 and 4 are fused in the area of their metapophyses, with fusion being pronounced to a greater extent on their left side (Fig. 12).

Pathologies in the thoracic and lumbar regions of the vertebral column caused by the use of riding horses were recorded in a number of works (Levine, 1999, 2005; Levine et al., 2000). Pathologies frequently developed because of pressure of the horseman sitting directly on the horse back, in particular, as the saddle design did not compensate non-uniform load on the horse vertebral column. The development of these processes could have been connected with the use of the soft saddles, which were widespread a thousand years $\mathrm{BC}$ and probably later.

Kirpichnikov (1973, p. 36) presumed the use soft or pad saddles in Europe at the beginning of the Middle Ages, i.e. "... low saddles, with low pommels, round (in cross-section) shelves and, probably, pad sitting." The pathologies marked in the thoracic and lumbar regions of the vertebral column of the stallion could have resulted from both intense use of saddled horse and natural ageing processes.

The skeleton belonged to a 15-16 years old stallion, with biologically good condition of bones. Notwithstanding the above pathological changes and other individual features of bones and teeth, its life-span was 


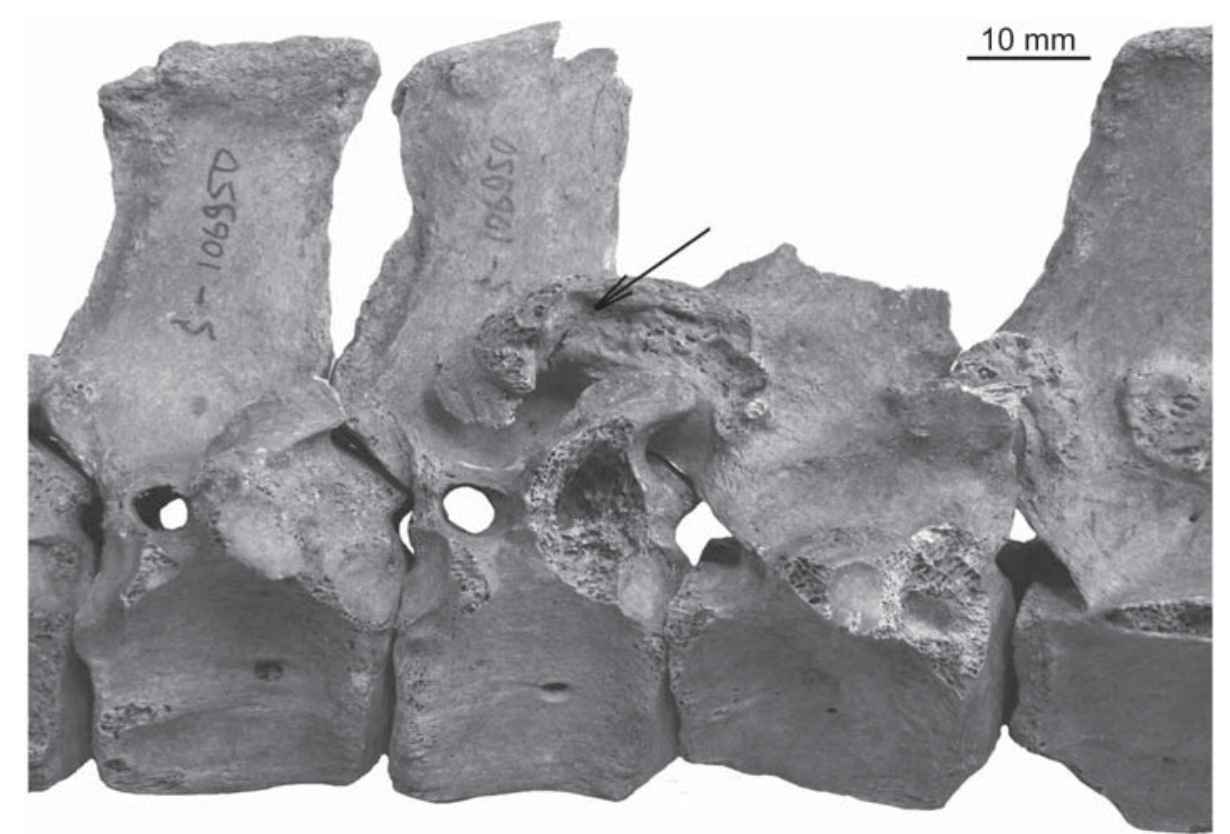

Fig. 11. Excessively strongly developed metapophysis of the 15 th thoracic vertebra in stallion from the Ts-142 burial (ZMMU, no. S-106950).

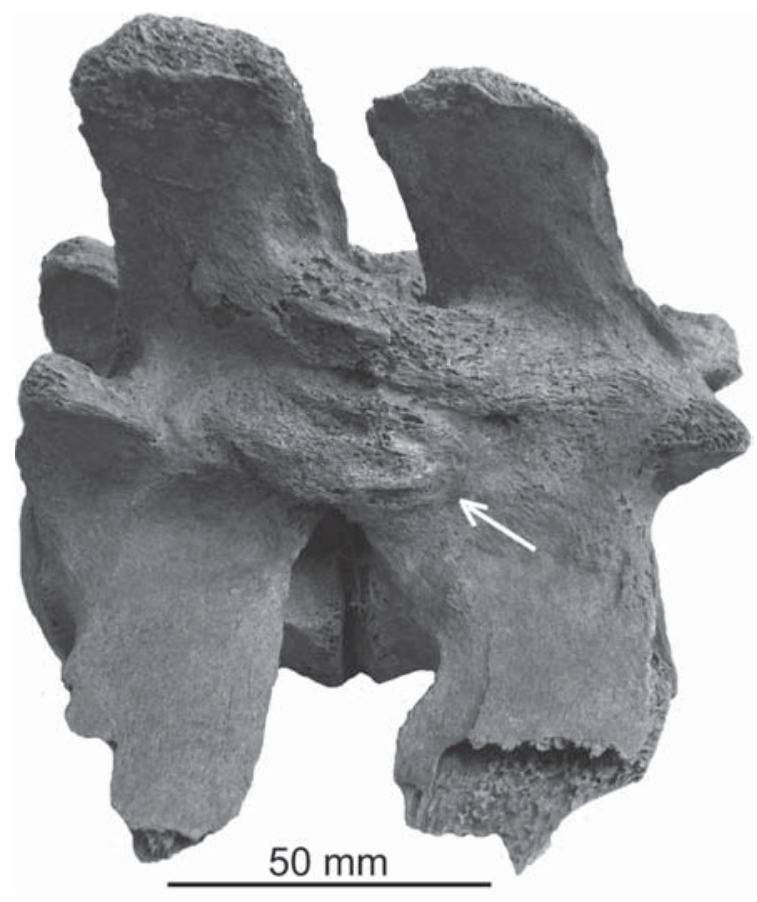

Fig. 12. Lumbar vertebrae 3 and 4 fused at metapophyses in stallion from the Ts-142 burial (ZMMU, no. S-106950).

rather long for medieval horses. The development of specific dental features of the stallion from burial Ts142 took a long time. The asymmetrical wear of cheek teeth was connected with the habit of gnawing at the bit mostly on the right side. At the same time specific wear of the upper corner teeth resulted from malocclusion, and greater manifestation of the character on the right side was probably caused by this habit.
The stallion was buried in a separate chamber, i.e. it did not fall into the burial by an accident. Perhaps its owner survived it. The situation is evidence of a high status of the owner, on the one hand, and special relation to the horse, on the other hand. This is indirectly confirmed by the conclusions derived from the bone material.

Predominant wear of premolars on the right side ("accumulated" feature) is probably accounted for by the horse belonging to the same owner.

A horse skeleton from the burial mound Ts-191. Almost all bones of this skeleton display distinct traces of charring. The compacta surface of other parts of the skeleton is apparently disrupted by leaching in active soil medium of the sites "weakened" by the thermal effect. A similar preservation pattern of the bones is characteristic of the Gnezdovo beds, which fall in the fire zone. At the same time, traces of the fire are frequently absent on the bone surfaces, but sometimes observed in the internal parts (spongy tissue) of bones.

Judging from the structure of dentition and wear pattern of the incisors, the skeleton belonged to a young stallion of 5-6 years old (6-7, after Andreeva, 1980). The specific wear of anterior premolars (Fig. 9) was probably caused by their constant friction against metal elements of the harness. The fact that the stallion was used saddled is supported by the presence of the bits and stirrups in the same burial.

Like the skeleton from burial Ts-142, this one shows individual morphological features as follows. Compacta of the first phalanges is charred strongly externally and disrupted. Only some sites of the proximal articular surfaces are preserved, although available specimens are sufficient to recognise that the phalanges are unusu- 

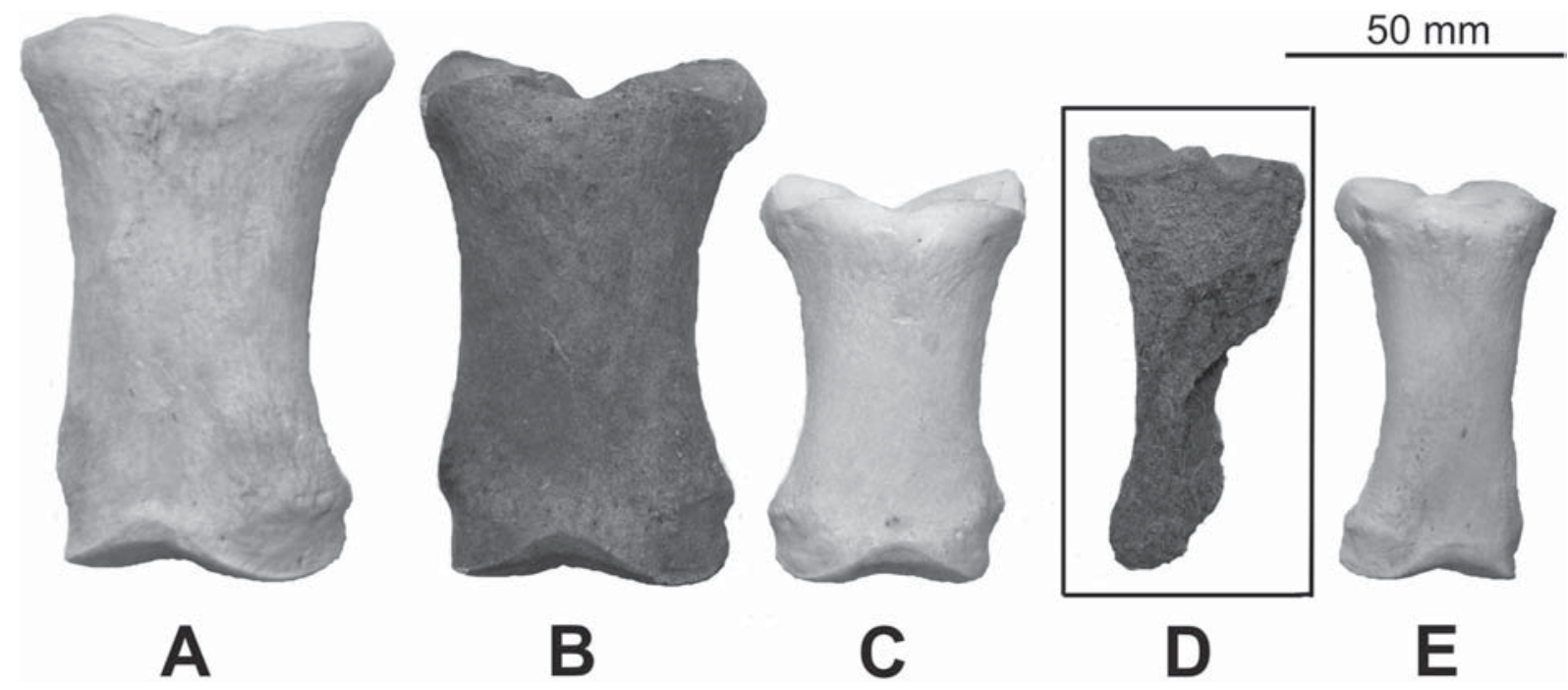

Fig. 13. First phalanges, anterior view: (A) living domestic horse, unknown breed (ZMMU, no. S-102019); (B) stallion from the Ts-142 burial (ZMMU, no. S-106950); (C) living domestic horse, Shetland pony (ZMMU, no. S-106942); (D) stallion from the Ts-191 burial (ZMMU, no. S-106951); (E) extant kulan (ZMMU, no. S-74802).

ally slender (Fig. 13). Based on a thorough examination of the phalanges, we concluded that the fire affected only the state of compacta, without changes in size and proportions of these bones.

However, other bones are usual in size and proportions. This feature made us to search for analogues among southern horse breeds, such as the Arabian or Akhal-Teke horses known for their slender legs. The bone length (estimated as $83 \mathrm{~mm}$ with correction for disruption by charring) falls within the dimensional range of the Arabian horse known to be usually 80-85 mm long (Kiesewalter, 1888; Osborn, 1907; Brauner, 1916). The Arabian horse has a wider upper end of the phalanx (57.5-59.1\% of the bone length) than donkeys (50.6\%) also having gracile phalanges (Brauner, 1916). In addition, the Arabian horse have rather thin metapodia; the width-to-length ratio of metatarsals is $9.9-11 \%$ (Chersky, 1881; Osborn, 1907; Clutton-Brock \& Burleigh, 1979). In the stallion from the burial Ts-191, this parameter is $10 \%$.

Stallion phalanges from burial Ts-191 look similar in proportions to phalanges of the domestic donkey. However, the structure of elements of occlusal surface of the cheek teeth, proportions of the skeleton and the structure of other bones undoubtedly show that they belong to the domestic horse (Equus caballus Linnaeus, 1758). To date, we have no comparative materials enabling precise allocation of the stallion in question to some particular breed group. We can hypothesise that it comes from remote (probably southern) rather than local areas (import or trophy?). A similar find of a very thin-legged stallion is known from a burial dated 1 century AD in the Karaganda Region. Its phalanges are similar in proportions to kulan, Hemionus hemionus Pallas, 1775 (Barmintsev, 1958, p. 24).

It should be emphasised that attempts of breed identification of the bone remains are objected frequently by experts. Such an identification based on dimensional parameters only is embarrassed by confusion of the breed characters with those caused by maintenance conditions. It is well known that pedigreed and large animals under unsatisfactory conditions (underfeeding, not heated stables etc.) may decrease in size, deviate from norm in various organs and systems, etc. However this process usually proportionally involves particular parts of organism (skeleton). Taking into account good biological state of the bones (excluding natural age changes), we propose that light and gracile first phalanges of the stallion from the burial Ts-191 are breed points rather than caused by its living conditions or individual features.

A horse skeleton from the burial mound Ts-255. Chamber burials in Gnezdovo are not numerous (Zharnov 1991). This type is represented by the burial mound Ts-255. It is designated in the Field Report as an inhumation (Avdusin et al., 1978; pp. 55-57). However, as it follows from the field description, excavations revealed a fire pit, ashen ring around the burial pit and ash and coal inclusions. It should be noted that the burial was occurring in an active soil strata for a long time, with intense processes of accumulation and washout of solutes. Apparently, ash inclusions are only remains of initially abundant products of the burnt organic matter. This factor probably affected many bones of the skeleton, as is revealed in the present study. However this is not always evident because of disruption of specimens in enclosing matter and during extraction of bones.

According to the field observation, the horse skeleton lays on its right side. A thorough study shown that bones on the left side were burnt to a greater extent than on the right side. Similar damage of thoracic and lumbar vertebrae (greater disruption of the left lateral processes) could have occurred when bones were extracted 
from enclosing matter because of their fragility resulting from the thermal effect. The character of damage of the skeleton suggests that the fire was set above the horse corpse.

\section{Habitus and size of the horses from medi-} eval Gnezdovo

Only a few horse bones found in the settlement are suitable for measurements. The metatarsal from a pit in the central part of the settlement is $242 \mathrm{~mm}$ long and $43.7 \mathrm{~mm}$ wide in its distal part (Kirillova, 2007). It was inferred from these data that the horse was $129 \mathrm{~cm}$ tall at the withers, i.e. "below average" according to the classification of Vitt (1952), it fits the "small" class by the bone length. The metatarsal from the floodplain part of the settlement (excavated in 2005) is $275 \mathrm{~mm}$ long and, hence, the horse was $146 \mathrm{~cm}$ tall at the withers - i.e. it fits the "medium" class, just as it does according Vitt's classificatoin. Andreeva (1980) provided measurements of a metacarpal from the settlement, which correspond to $127 \mathrm{~cm}$ of height at the withers ("small" after Vitt).

Based on the metapodia measurements, the height at withers of the stallion from burial mound Ts-142 was estimated as 147.7-150.6 cm — "above average" (after Vitt). Based on the measurements of humerus, radius, femur, metacarpal this horse was regarded as "medium", but it was considered to be "above average" based on its tibia and metatarsus cannon bones measurements (after Vitt); this agrees with conclusions made by Andreeva (1980).

It is impossible to measure the majority of the horse bones from burial mound Ts-191 because of their poor preservation. However, it seems plausible that this stallion was medium-sized. The height at withers estimated by us based on the metatarsal length is $138 \mathrm{~cm}$, this agrees with the assignment of this horse to the mediumsized class or possibly "below average" by its bone lengths (after Vitt).

The animal from burial mound Ts-255 was about $145 \mathrm{~cm}$ ("above average" after Vitt) However, it belongs to the "medium" group according to its tibia and metatarsus lengths and to the "below average" group according to the remaining bones (probably due to their being damaged).

Horses from Gnezdovo are rather diverse in size; horses from the settlement ("working") are 127.5-146.5 $\mathrm{cm}$ tall at the withers; horses from the burial mounds ("riding") are 138-150.6 cm tall. Horses from Gnezdovo are somewhat larger than contemporaneous horses: 136.7-138.8 (Novgorod: Tsalkin, 1956), 142 (Novgorod, Rurik's central hillfort: Sablin, 2007), 135.3-137.8 (Pskov: Tsalkin, 1956), and 117-131 cm tall (Latvia: Bertasius \& Daugnora, 2001). However, it is to be noted that these estimates are applied only to the individuals currently suitable for examination, while involvement of a more representative new sample of at least two or three dozen medieval horses from Gnezdovo can change them.
Chersky (1881) and subsequently Brauner (1916) proposed a classification of the horses based on the width-to-length ratio of their metacarpals. According to this classification, the stallion from burial mound Ts142 belongs to the medium-legged group. At the same time, most of the horses from Rurik's central hillfort of Novgorod belong to the semithin-legged type (Sablin, 2007). In Grodno (12th and 13th centuries), all horse types have been recorded, although semithin-legged and medium-legged forms prevailed (Tsalkin, 1954).

Thus, it is evident that, in the early Middle Ages, a wide range of the dimensional and constitutional horse types was characteristic not only to Gnezdovo but also to other sites (see, for example, Swiezynski et al., 1989).

\section{Taphonomic remarks}

A thorough study of preservation of the above horse skeletons from the Gnezdovo burials (Ts-191, Ts-255) shown that they are similar in taphonomy to each other and to the specimens from the "Pozhar 1" layer.

Both horse skeletons (corpses) undoubtedly underwent the influence of fire. ${ }^{1}$ Judging from the character of damages, an effect of the fire on the bones was not necessarily direct (as in the case the corpse were put into a fire place). In both cases, bones burnt to whiteness (calcined, as in other burials of Gnezdovo) have not been recorded (Andreeva, 1980). According to the colour scale developed for reconstruction of the temperature effect on cremated remains (Walker et al., 2008, Fig. 19-23), horse skeletons from the burial mounds Ts-191 and Ts-255 were exposed to a relatively low temperature corresponding to "grey charring", i.e. approximately $200^{\circ} \mathrm{C}$.

However two points should be kept in mind. First, this value is rather approximate and may require correction, which is beyond the scope of the present study. (In addition, we were not intended here to prove by physical and chemical methods the fact that the state of bones was caused by fire rather than any other thermal factor; we adhered to the "fire" version, since it seems evident). Second, as it follows from the above description of a number of skeleton parts, they were exposed to different temperatures, as some bones are charred to blackness, others look unaffected by the fire. Thus our temperature reconstructed based on prevailing colour of the bone surfaces is rather rough.

The above damage types of bones connected with a relatively low temperature of burning was probably developed because of the following:

1. the horse corpse were completely or partially covered with soil and the fire was set above it, i.e. the fire had an indirect effect;

2 . wooden building enclosing a corpse was burnt (Ts-191) and burning was not completed for some reason;

We had no way of studying human skeletons from these burials. In the Field Reports (Avdusin et al., 1976; Avdusin et al., 1978 ) the inhumation rite was recorded (see above). 
3. thermal influence was more or less remote;

4. the horse corpse was in a fire pit (i.e. without open flame) or covered with the smoldering coals.

Traces of fire on the horse bones from the burials of Gnezdovo were previously described in detail by Sizov (1902). In particular, he found a slightly scorched complete horse skeleton in an isolated burial with a few artefacts. Regarding this finding, he assumed that the horse was killed and burnt in the fire of a large burial mound and then brought with some coals and artefacts which did not belong to the horse furniture (p. 11) Another burial contained a horse skeleton lying on a charred board overlying charred logs. This was underlain by a fire pit covering the entire surface of excavation of the burial mound. Sizov proposed that the horse has been killed before it was put on the board among large hot coal pieces and covered with them (p. 12).

Sizov's interpretation agrees with the results of our taphonomic study of the horse skeletons from the Ts191 and Ts-255 burials.

The study of the horse skeletons from the burial mounds of Gnezdovo shown that these were personal rather than simply riding horses ("a horse of its saddle"). These individual, but prominent cases of buried horses suggest a special (maybe battle?) status of the horses and particular importance of the pair "warriorhorse." Some workers believe that burials of this kind reflect a social character emphasising the role of military elite (Solov'eva, 1971; Kulakov, 1990).

\section{Conclusion}

The study of the horse remains from the Gnezdovo archaeological complex has shown the following:

1. The kitchen midden of settlement and central hillfort contains rather few remains of exclusively adult animals, suggesting that they were used up to complete depletion of their resources.

2. These horses belong to the small and smallmedium size classes. The horses from the burial mounds are somewhat larger than those from the settlement. The habitus and individual morphological and morphometric characteristics of the horses from three burial mounds of the Central group (Ts-142, Ts-191 and Ts255) are evidence of heterogeneous breed composition and origin of these animals. This agrees with the heterogeneous ethnic composition of human population revealed by anthropologists based on the presence of imported artefacts.

3. Taphonomic features of the horse bones from the Ts-255 burial show that the generally accepted treatment of materials of the burial as inhumation requires correction. This concerns at least horse remains.

4. The specificity of medieval Gnezdovo burials with horses (separate horse burial; burial of a horseman together with horse; horse belonging to one owner; sacrifice) shows special relation of local people to riding horses.
ACKNOWLEDGEMENTS. We are grateful to T.A. Pushkina for an opportunity to use archival materials, to A.B. Kuz'min for help with taking photographs, and to P.A. Kosintsev and I.Y. Pavlinov for scientific editing and valuable advice, G.S. Rautian for editing the article. Funding for the work carried out by National Alliance of Shidlovskiy "Ice Age".

\section{References}

Antony D.W. \& Brown D.R. 1989. Looking a gift horse in the mouth: Identification of the earliest bitted equids and the microscopic analysis of wear // MASCA Research Papers in Science and Archaeology. Vol.6. P.99-116.

Andreeva E.G. 1963. [Fauna from the Volga Region near Yaroslavl based on bone remains from burial mounds of the $10^{\text {th }}-11^{\text {th }}$ centuries] // Smirnov A.P. (ed.). [Yaroslavl Volga region in 10-11 centuries]. Moskva. P.92-95 [in Russian].

Andreeva E.G. 1980. Bone materials from Gnezdovo // Sovetskaya Arkheologiya. No.1. P.56-63 [in Russian].

Avdusin D.A. 1991. [Urgent questions of the study of ancient Smolensk and its nearest outskirts] // Avdusin D.A. (ed.). [Smolensk and Gnezdovo (to History of Old Russian City). Moskva: Izdatel'stvo MGU. P.3-20 [in Russian].

Avdusin D.A., Astashova N.I. \& Kamenetskaya E.V. 1975. [Unpublished report on excavations in Smolensk and Gnezdovo of the Smolensk Archaeological Expedition in 1975] // Arkhiv Instituta arkheologii Akademii nauk SSSR. R-1. No.5913 [in Russian].

Avdusin D.A., Astashova N.I. \& Pushkina T.A. 1976. [Unpublished report on work of the Smolensk Archaeological Expedition of Lomonosov Moscow State University in 1976] // Arhiv Instituta arheologii Akademii nauk SSSR. R-1. No.6150 [in Russian].

Avdusin D.A., Kamenetskaya E.V. \& Pushkina T.A. 1978. [Unpublished report on excavations in Gnezdovo in 1978] // Arhiv Instituta arheologii Akademii nauk SSSR. R-1. No.8395 [in Russian].

Barmintsev J.N. 1958. [Evolution of Horse Breeds in Kazakhstan]. Alma-Ata: Kazgosizdat. 284 p. [in Russian].

Bendrey R. 2007. New methods for the identification of evidence for bitting on horse remains from archaeological sites // Journal of Archaeological Science. Vol.34. P.1036-1050.

Bertasius M. \& Daugnora L. 2001. Viking age horse graves from Kaunas region (Middle Lithuania) // International Journal of Osteoarchaeology. Vol.11. P.387-399.

Brauner A.A. 1916. [Data on domestic animals in Russia: 1. A horse from burial mounds of Tiraspol District of the Kherson Region] // Zapiski Imperatorskogo Obshchestva Sel'skogo Khozyaistva Yuzhnoi Rossii (Odessa). Vol.86. No.1. P.1-168 [in Russian].

Chersky I.D. 1891. [Description of Post-Tertiary mammals collected by the New Siberian Expedition in 1885-1886] // Zapiski Imperatorskoi Akademii Nauk (St. Petersburg). Appendix 65. No.1. 706 p. [in Russian].

Clutton-Brock J. \& Burleigh R. 1979. Notes on the osteology of the Arab horse with reference to a skeleton collected in 
Egypt by Sir Flinders Petrie // Bulletin of British Museum of Natural History (Zoology). Vol.35. No.2. P.191200.

Dyurst U. 1936. [The Horse Exterior]. Moskva-Leningrad: Sel'khozgiz. 344 p. [in Russian].

Eisenmann V., Alberdi M.T., De Giuli C. \& Staesche U. 1988. Studying fossil horses // Woodburne M. \& Sondaar P. (eds.). Collected Papers after the "New York International Hipparion Conference, 1981”. Vol.1. Leiden: Brill E.J. P.1-71.

Ermolova N.M. 1967. [Unpublished report on work of Dnieper Archaeological Expedition of the Institute of Archaeology (Leningrad Department) of the Academy of Sciences of the USSR]. // Arkhiv Instituta istorii material'noy kulturu RAN. F-48. No.459 [in Russian].

Gromova V.I. 1949. [History of horses (genus Equus) in the Old World: Review and description of forms. Part 1] // Trudy Paleontologicheskogo Instituta Akademii Nauk SSSR. Vol.17. No.1. 373 p. [in Russian].

Gromova V.I. 1959. [On a tarpan skeleton (Equus caballus gmelini Ant.) and other extant wild horses. Part 1] // Bulleten' Moskovskogo Obshchestva Ispytatelei Prirody. Seriya Biologicheskaya. Vol.64. No.4. P.99-124 [in Russian].

Gromova V.I. 1963. [On a tarpan skeleton (Equus caballus gmelini Ant.) and other wild horses. Part 2] Trudy Moskovskogo Obshchestva Ispytatelei Prirody. Seriya Biologicheskaya. Vol.10. P.10-61 [in Russian].

Kiesewalter L. 1888. Skelettmessungen am Pferde ais beitrad zur theoretischen grundlage der beurteilungslehre des Pferdes. Leipzig: Inaug. Dissert. $39 \mathrm{p}$.

Kirillova I.V. 2007. [Bone materials from cultural layers of Gnezdovo: New data] // Murasheva V.V. (ed.). [Gnezdovo: The results of a comprehensive study of the complex]. St. Petersburg: Izdatel'stvo Alfaret. P.118-129 [in Russian].

Kirpichnikov A.N. 1973. [Equipment of a horseman and riding horse in Russia in the $9^{\text {th }}-13^{\text {th }}$ centuries] // Arkheologiya SSSR: Svod Arkheologicheskikh Istochnikov. E1-36. 139 p. [in Russian].

Korneven Sh. \& Lesbr F.-K. 1932. [Recognition of Age Based on Teeth and Derivatives of Epithelium]. Moskva-Leningrad: Izdatel'stvo Sel'skokhozyaistvennoi i Kolkhozno-Kooperativnoi Literatury. 213 p. [in Russian].

Kulakov V.I. 1990. [Antiquity of Prussia of VI-XIII Centuries]. Moskva: Nauka. 166 p. [in Russian].

Kuleshov P.K. \& Krasnikov A.S. 1928. [Age Determination in Agricultural Animals]. Moskva: Gosudarstvennoe Izdatel'stvo. 120 p. [in Russian].

Levine M.A. 1999. The origins of horse husbandry on the Eurasian steppe // Levine M., Rassamakhin Y., Kislenko A. \& Tatarintseva N. (eds.). Late Prehistoric Explotation of the Eurasian Steppe. Cambridge: McDonald Institute Press. P.5-58.

Levine M.A. 2005. Domestication and early history of the horse // Mills D.S. \& McDonnell M. (eds.). The Domestic Horse: The Origins, Development, and Managements of Its Behaviour. Cambridge: Cambridge University Press. P.5-22.

Levine M.A., Bailey G.N., Whitwell K.E. \& Jeffcott L.B. 2000. Palaeopathology and horse domestication: The case of some Iron Age horses from Altai Mountains, Siberia // Bailey G., Charles R. \& Winder N. (eds.). Human Ecodynamics and Environmental Archaeology. Oxford: Oxbow. P.23-133.

Osborn H.F. 1907. Points of the skeleton of the Arab horse // Bulletin American Museum of Natural History. Vol.23. P.259-263.

Sablin M.V. 2007. [New studies of faunal remains from the Rurik's ancient settlement] // [Novgorod and Novgorod Arce: History and Archeology]. Velikiy Novgorod. Vol.21. P.310-312 [in Russian].

Sedov V.V. 1957. [On the question of sacrifices in Ancient Novgorod] // Kratkie soobschenia Instituta istorii materalnoy kulturu Akademii nauk SSSR. Vol.68. P.20-28 [in Russian].

Sedov V.V. \& Sedova M.V. 1983. [Ancient Suzdal: Archeologikal investigation] // Vestnik AN SSSR. No.1. P.130138 [in Russian].

Sedova M.V. \& Belen'kaya D.A. 1981. [Roundabout city of Suzdal] // Sedov V.V. (ed.). [Old Russian Cities]. Moskva: Nauka. P.95-115 [in Russian].

Sizov V.I. 1902. [Burial Mounds of the Smolensk Region. Part 1]. // [Materialy po archeologii Rossii.]. No.28. St. Petersburg: Tipografiya Glavnogo Upravleniya Udelov. 162 p. [in Russian].

Solov'eva G.F. 1971. [On the role of Baltic substrate in the history of Slavic tribes of the upper Dnieper Region] // Sovetskaya Arkheologiya. No.2. P.124-132 [in Russian].

Spasskaya N.N. 2003. [Estimation of the horse height by indirect methods] // [Theriofauna of Russia and adjacent territories]. // Materials of VII Congress Russian Theriological Society. Moskva: KMK. P.336-337 [in Russian].

Spitsyn A.A. 1905. [Gnezdovo burial mounds in excavations of S.I. Sergeev] // Ezhegodnik Archeologicheskoi Komissii. Vol.15. P.6-70 [in Russian].

Swiezynski K., Serwatka S. \& Kobryn H. 1989. Szczatiki konia Equus przewalskii f. caballus (Pallas, 1811) w materialach wykopaliskowych z skedniowiloznego crodu w Kaliszu-Zawodzin // Archaeologia Polski. Vol.34. No.2. P.391-427.

Tsalkin V.I. 1954. [Fauna from excavations in Grodno] // Voronin N.N. (ed.). [Very old Grodno (According to archaeological excavations 1932-1942.)] // [Materialy i issledovania po arheologii drevnerusskih gorodov.]. Moskva. Vol.3. P.211-236 [in Russian].

Tsalkin V.I. 1956. [Materials of the history of cattle breeding and a hunting in ancient Russia] // Materialu i issledovania po arheologii SSSR. Moskva: Izdatel'stvo Academia Nauk SSSR. 185 p. [in Russian].

Vitt O.V. 1952. [Horses from Pazyrykskie burial mounds] // Sovetskaya Arkheologiya. No.16. P.163-205 [in Russian].

Walker Ph.L., Kevin W.P., Miller K.W. \& Richman R. 2008. Time, temperature, and oxygen availability: An experimental study of the effects of environmental conditions on the color and organic content of cremated bone // Schmidt C.W. (ed.). Burned Bone. P.129-135.

Zharnov Yu.E. 1991. [Scandinavian woman burials in Gnezdovo] // Avdusin D.A. (ed.). Smolensk i Gnezdovo (v Istorii Starogo Russkogo Goroda). Moskva: MGU. P.200255 [in Russian]. 
Zharnov Yu.E. 1992. [Funeral Ceremony in Ancient Russia Based on Materials from Gnezdovo Necropolis]. PhD Thesis. Moskva: Moskovskyi Gosudarstvennyi Universitet. 450 p. [in Russian]. 